Review

\title{
Sexual Dysfunctions Related to Drugs Used in the Management of Lower Urinary Tract Symptoms Due to Benign Prostatic Hyperplasia: A Narrative Review on $\alpha$-Blockers and 5-Alpha Reductase Inhibitors
}

\author{
Antonio La Torre ${ }^{1}$, Caterina Palleria ${ }^{2}$, Irene Tamanini ${ }^{3}$, Andrea Scardigli ${ }^{3}$, Tommaso Cai ${ }^{3,4, *(D),}$ \\ Manuela Colosimo ${ }^{5}$, Lucia Muraca ${ }^{6}$, Vincenzo Rania ${ }^{2}$, Davida Mirra ${ }^{2}$, Alessandro Casarella ${ }^{2}$, \\ Gianmarco Marcianò ${ }^{2}$, Giovambattista De Sarro ${ }^{2,7}$ and Luca Gallelli ${ }^{2,7}$ (D)
}

1 Operative Unit of Psychiatry, Santa Maria del Carmine Hospital, 38068 Rovereto, Italy; antonio.latorre@apss.tn.it

2 Operative Unit of Clinical Pharmacology and Pharmacovigilance, Mater Domini University Hospital, Department of Health Science, University of Catanzaro, 88100 Catanzaro, Italy; palleria@unicz.it (C.P.); raniavincenzo1@gmail.com (V.R.); davidamirra92@gmail.com (D.M.); al.cas1993@gmail.com (A.C.); gianmarco.marciano@libero.it (G.M.); desarro@unicz.it (G.D.S.); gallelli@unicz.it (L.G.)

check for updates

Citation: La Torre, A.; Palleria, C.; Tamanini, I.; Scardigli, A.; Cai, T.; Colosimo, M.; Muraca, L.; Rania, V.; Mirra, D.; Casarella, A.; et al. Sexual Dysfunctions Related to Drugs Used in the Management of Lower Urinary Tract Symptoms Due to Benign Prostatic Hyperplasia: A Narrative Review on $\alpha$-Blockers and 5-Alpha Reductase Inhibitors. Uro 2021, 1 , 82-98. https://doi.org/10.3390/ uro1030012

Academic Editor: Pawel Miotla

Received: 7 June 2021

Accepted: 24 June 2021

Published: 5 July 2021

Publisher's Note: MDPI stays neutral with regard to jurisdictional claims in published maps and institutional affiliations.

Copyright: (c) 2021 by the authors. Licensee MDPI, Basel, Switzerland. This article is an open access article distributed under the terms and conditions of the Creative Commons Attribution (CC BY) license (https:// creativecommons.org/licenses/by/ $4.0 /)$.
3 Department of Urology, Santa Chiara Regional Hospital, 38100 Trento, Italy; irene.tamanini@apss.tn.it (I.T.); andrea.scardigli@apss.tn.it (A.S.)

4 Institute of Clinical Medicine, University of Oslo, 0010 Oslo, Norway

5 Operative Unit of Microbiology, Pugliese-Ciaccio Hospital, 88100 Catanzaro, Italy; manuelacolosimo@hotmail.it

6 General Medicine, Azienda Sanitaria Provinciale 7 Catanzaro, 88100 Catanzaro, Italy; luciamuraca@libero.it 7 Research Center FAS@UNICZ, Department of Health Science, University of Catanzaro, 88100 Catanzaro, Italy * Correspondence: ktommy@libero.it; Tel.: +39-0461-903306 or +39-3339-864943; Fax: +39-0461-03101

\begin{abstract}
This is a critical review of the current literature data about sexual dysfunction as a potential side effect related to drugs commonly used for the treatment of Benign Prostatic Hyperplasia and Lower Urinary Tract Symptoms. In this narrative review, we analyzed data from the literature related to the development of sexual dysfunctions during the treatment of BPH or LUTS. Both $\alpha$-blockers and 5-alpha reductase inhibitors (5-ARIs) can induce erectile dysfunction, ejaculatory disorders and a reduction in sexual desire. The sexual side effect profile of these drugs is different. Among the $\alpha$-blockers, silodosin appears to have the highest incidence of ejaculatory disorders. Persistent sexual side effects after the discontinuation of finasteride have been recently reported; however, further studies are needed to clarify the true incidence and the significance of this finding. However, most of the published studies are affected by a weak methodology and other important limitations, with only a few RCTs available. Therefore, it is desirable that future studies will include validated tools to assess and diagnose the sexual dysfunction induced by these medications, especially for ejaculation and sexual desire disorders.
\end{abstract}

Keywords: $\alpha$-blockers; 5-alpha reductase inhibitors; Benign Prostatic Hyperplasia (BPH); LUTS (Lower Urinary Tract Symptoms); sexual side effects

\section{Introduction}

Sexual dysfunctions are commons in elderly men [1-5], even if they could be adverse drug reactions (ADRs) of antidepressants, antipsychotics and anti-hypertensive drugs [6-12]. Moreover, $\alpha$-blockers and 5-alpha reductase inhibitors (5-ARIs) can induce erectile dysfunction and ejaculatory disorders [5,9,13-19], despite these drugs being used to treat Benign Prostatic Hyperplasia (BPH) and Lower Urinary Tract Symptoms (LUTS) that induce sexual dysfunction [20-24]. In this manuscript we reviewed data from the literature related to the development of sexual dysfunctions during the treatment of $\mathrm{BPH}$ or LUTS. 


\section{Materials and Methods}

The PubMed, Embase and Cochrane library databases were searched for articles published before 15 February 2021. Secondary search included articles cited in reference lists identified by the primary search. Records were first screened by title/abstract, before full-text articles were retrieved for eligibility evaluation. Remaining articles were then subject to a citation search before a final hand-search of all reference lists. Papers were deemed eligible if they included any form of the following words: "sexual dysfunction", "drugs", "carotid atherosclerosis", " $\alpha$-blocker", "5-alpha reductase inhibitors", "phosphodiesterase type 5 inhibitors", Benign Prostatic Hyperplasia (BPH), LUTS (Lower Urinary Tract Symptoms), "sexual side effects" and "treatment-emergent sexual dysfunction". All citations were downloaded in Mendeley Ltd. software (Elsevier, London, UK), and duplicates were deleted. A.L.T. and C.P. screened all articles by title/abstract to determine their eligibility and L.G. reviewed a random sample of $20 \%$ in order to evaluate the reliability of the selection process. In order to avoid a bias of exclusion, the full text articles were retrieved following first round exclusions and were also subject to two independent eligibility reviews (T.C. $100 \%$, G.D.S. $20 \%$ ), this time with perfect agreement. The studies evaluated as eligible are enclosed in the present narrative review.

\section{Results}

All the reviewed articles are listed in Tables 1 and 2. In Table 1, we indicated the articles on sexual dysfunction related to the drugs used in the treatment of LUTS and/or $\mathrm{BPH}$, while in Table 2 the articles on phosphodiesterase type 5 inhibitors (PDE5i) used in LUTS and/or BPH are listed.

Table 1. Sexual dysfunction related to drugs used in the treatments of LUTS and/or BPH.

\begin{tabular}{cc}
\hline Manuscripts & References \\
\hline Reviews and meta-analysis: 58 & {$[9,13-15,17,18,20-72]$} \\
\hline RCTs (Randomized Clinical Trials): 21 & {$[73-93]$} \\
\hline $\begin{array}{c}\text { Clinical trials, Case Control, Retrospective studies, } \\
\text { Surveys and “Case reports": } 41\end{array}$ & {$[1,2,5,18,64,94-129]$} \\
\hline Others: 57 & {$[3,6-11,16,19,48,130-171]$} \\
\hline
\end{tabular}

Table 2. Manuscripts on PDE-5i used to treat LUTS and/or BPH.

\begin{tabular}{cc}
\hline Manuscripts & References \\
\hline Reviews and meta-analysis: 30 & {$[92,172-201]$} \\
\hline RCTs: Randomized Clinical Trials: 24 & {$[78,202-224]$} \\
\hline Others (non RCTs): 9 & {$[126,189,225-231]$} \\
\hline
\end{tabular}

As reported in Table 1 , most of the articles $(58 ; 36.9 \%)$ are reviews and meta-analyses, while only $21(12.7 \%)$ are randomized studies (RCTs: Randomized Clinical Studies, such as randomized, double-blind, placebo-controlled studies) and only 2 of these [82,85] used a specific and validated rating scale to measure sexual function. In contrast, among the 41 non-RCT studies (24.8\%) (Table 1), 32 (78\%) used a specific questionnaire (mainly IIEF) to detect sexual dysfunction, while $9(22 \%)[96,97,106,110,112,114,115,120,129]$ did not use any validated rating scale.

Both $\alpha$-blockers and 5-ARIs can cause erectile dysfunction, ejaculatory disorders and a reduced sexual desire $[35,232]$ (we have sorted the pharmacologic effects by sexuality as "excitatory" (+), "inhibitory" (-) or "no effect" (+/-); we also defined as "uncertain" (?) the results that were difficult to interpret). 


\section{1. $\alpha$-Blocker}

Both silodosin and tamsulosin induce ejaculatory disorders (up to 28.1\%) [91] (Tables 3-5). The different sexual side effect profile of $\alpha$-blockers may be related to the following several factors: (1) the chemical structure; (2) the binding affinity/selectivity for $\alpha 1$-adrenergic receptor subtypes; (3) binding to other receptor-mediated mechanisms; and (4) the different volume of distribution. Alfuzosin, doxazosin and terazosin show equal binding with the three subtypes of $\alpha 1$-adrenergic receptors, while tamsulosin and silodosin show a superselective binding with the $\alpha 1-\mathrm{A}$ receptor $[4,14,43]$. The most uroselective alpha-blocker is silodosin and has the most marked effect on ejaculation [23,113]. The sexual side effect profile of dutasteride appears to be similar to that of finasteride with regards to erectile dysfunction (ED), ejaculatory dysfunction (EjD) and decreased libido [72,123,140]; both drugs appear to be associated with a higher risk of ED, EjD and reduced libido than a placebo [30,131,233]. Recently, Corona et al. [125] found that 5-ARIs are associated with decreased libido and spontaneous nocturnal erection, while no relationship was found with ED or EjD.

Table 3. Effects of $\alpha$-blockers on erectile functions.

\begin{tabular}{|c|c|c|c|c|}
\hline Silodosin & Tamsulosin (II) $(\nabla)$ & Alfuzosin (II) & Terazosin & Doxazosin (II) \\
\hline \multirow[t]{2}{*}{$(+/-)[82]$} & $\begin{array}{c}(+/-) \\
{[16,19,53,90,98,121,122,140]} \\
(+)\end{array}$ & $\begin{array}{c}(+/-) \\
{[16,19,53,75,86,90,140]} \\
(+)\end{array}$ & $\begin{array}{c}(+/-) \\
{[16,19,53,140]} \\
(+)\end{array}$ & $\begin{array}{c}(+/-) \\
{[16,19,53,98,140]} \\
(+)\end{array}$ \\
\hline & {$[101,103,107,116]$} & $\begin{array}{c}{[31,64,79,98,101,102,111,118,119,} \\
122,128,234]\end{array}$ & [107] & {$[33,77,105,107,127,235]$} \\
\hline
\end{tabular}

(II) There are, apparently, conflicting data on the effects of alfuzosin, doxazosin and tamsulosin on sexual function: some authors suggest a placebo-like effect, while others an improvement. The methodological problems concerning the various studies are detailed in a review by van Dijk et al. [50]. Methodological problems are likely responsible for some of the contradictory findings on sexual side effects [31]. (v) Hellstrom and Sikka [87] reported that in about $90 \%$ of health volunteers treated with tamsulosin $(0.8 \mathrm{mg} /$ day) a significant decrease $(20 \%)$ in the volume of ejaculation was recorded. Leliefeld et al. [108] failed to report the effect of $\alpha$-blockers. Several authors considered gynecomastia as a sexual dysfunction. This side effect has been reported in some manuscripts on $\alpha$-blockers [72,115].

Table 4. $\alpha$-blockers: Effects on ejaculator function.

\begin{tabular}{ccccc}
\hline Silodosin & Tamsulosin & Alfuzosin & Terazosin & Doxazosin \\
\hline$(-)$ & $(-)$ & $(+/-)$ & $(+/-)$ \\
$\left(1^{* *}\right)$ & $\left(2^{* *}\right)$ & {$[53,75,79]$} & $(+/-)$ & {$[14,53]$} \\
$(14,43,73,74,80,82,83,88,89,91,106$, & {$[14,75,87,96,116,117,120,236]$} & {$[64,118,119,122,128]$} & {$[14,53]$} & $(+)$ \\
$110,112-114]$ & & {$[105]$} & $(+)$ \\
\hline
\end{tabular}

$\left(1^{* *}\right)$ The prevalence of silodosin-induced ejaculation dysfunction (EjD) is between 5 and $28.1 \%$, with an average value of about $20 \%$ [159]: silodosin appears to be the drug with the highest risk of EjD [14,23]; these data are also confirmed by Capogrosso et al. [113], who report $48 \%$ of cases of anejaculation. The efficacy of silodosin appears to be increased in patients with "abnormal ejaculation" [112]. ( $\left.2^{* *}\right)$ The prevalence of tamsulosin-induced ejaculation dysfunction ranges from 3 to $11 \%[53,236]$ : tamsulosin is associated with a significantly lower risk of ejaculatory disorders than silodosin [14]. In studies by Hellstrom and Sikka [87] and Hisasue et al. [96], ejaculation disorders due to tamsulosin (decreased ejaculate volume and anejaculation) were not attributed to retrograde ejaculation.

Table 5. Effects of $\alpha$-blockers on sexual desire.

\begin{tabular}{ccccc}
\hline Silodosin & Tamsulosin & Alfuzosin & Terazosin & Doxazosin \\
\hline & $(+)$ & $(+)$ & & $(+)$ \\
$(-)$ & {$[116]$} & {$[64,122]$} & $(+/-)$ & {$[105]$} \\
{$[113]$} & $(+/-)$ & $(+/-)$ & {$[53,54]$} & $(+/-)$ \\
& {$[53,54,121]$} & {$[53,54]$} & & {$[53,54,92]$} \\
\hline
\end{tabular}

\section{2. $5-A R I$}

The sexual ADRs of 5-ARIs are comparable to placebos after a 2-year treatment $[27,72,81,115]$. Kaplan et al. [104] reported that a chronic treatment (5 years) with dutasteride induces a higher incidence of erectile dysfunction and gynecomastia than finasteride. Cases of persistent sexual dysfunction have been recently reported after the discontinuation of finasteride $[32,60,97,99,100,129,131,134,141,147,149,166,170]$. Irwig and 
Kolukula [99], using the Arizona Sexual Experience Scale (ASEX) validated questionnaire, interviewed 71 healthy male (21-46 years) finasteride-users, finding a high incidence of sexual dysfunction (Tables 6 and 7). In particular, 69-94\% of those interviewed described "low libido" (94\%), "erectile dysfunction" (92\%), "decreased arousal" (92\%) and "problem with orgasm" (69\%). The same authors acknowledged the limitations of their study, stating that "the true incidence of these events is unknown as it is a post-hoc approach" and that, in previous randomized, placebo-controlled trials, the incidence of ADR on sexual function was $8 \%$ lower in the finasteride group and less than $3 \%$ in the control group. "Assuming the vast majority of these events have resolved, the incidence of persistent sexual side effects in patients receiving finasteride was less than 1\%" [99]. Indeed, some methodological "biases", such as the following, could limit these results: (i) the study was conducted only through "standardized telephone or Skype interviews"; (ii) the study was conducted on a sample of patients recruited from a website for people complaining of sexual dysfunction; and (iii) the study was an observational survey (with no control groups) and involved only a small number of patients. The pathophysiological mechanisms responsible for 5-ARI-induced sexual dysfunction may be related to the decrease in dihydrotestosterone levels and possibly other neurosteroids, such as progesterone metabolites $[32,47,133]$. Psychological factors ("nocebo effect") have also been implicated as responsible for sexual dysfunction in patients treated with 5-ARIs [144]. However, to date, little is known about the exact mechanisms underlying the sexual dysfunctions related to 5-ARIs [61,71]. There is a cumulative risk of sexual ADRs with $\alpha$-blockers vs. monotherapy or a placebo [40,65,85,92,112]: Gacci and co-authors [14] found that combination therapy with $\alpha$-blockers and 5-ARIs resulted in a three-fold increased risk of ejaculation disorders vs. monotherapy.

Table 6. 5-ARI: Effects on sexual function.

\begin{tabular}{ccc}
\hline & Dutasteride (A), (B), (C) & Finasteride (A), (B), (C), (D) \\
\hline Effects on & $(-)$ & $(-)$ \\
erectile function & {$[27,34,40,48,49,71,76,93,112,123$,} & {$[34,48,49,71,77,81,85,92,140]$} \\
& $140]$ & $(+/-)$ \\
& $(+/-)$ & {$[125]$} \\
& {$[125]$} & $(?)$ \\
& $(-)$ & {$[59]$} \\
\hline Effects on & {$[14,27,48,49,61,71,76,84,123,140]$} & $(-)$ \\
ejaculatory function. & $(+/-)$ & $(14,48,49,59,71,77,81,85,92,140]$ \\
& 125 & 125 \\
\hline Effects on sexual desire. & $(-)$ & $(-)$ \\
& {$[27,40,48,49,76,84,93,123,125,140]$} & {$[48,49,77,81,85,92,125,140]$}
\end{tabular}

(A) Both finasteride and dutasteride exhibit comparable sexual effects and side effects [72,140]. A study by Lee et al. [34] however, reports a doubled risk of ED with finasteride. (B) The rates of these adverse effects become comparable to placebo after treatment has continued for more than 2 or more years $[115,140]$. Contrary to these data, recently Kaplan et al. [104] found that, over the long term (5 years), dutasteride causes significantly more sexual side effects and breast complications (gynecomastia) than finasteride. (C) In a review of clinical trials by Anitha et al. [59], the authors concluded that there was no clear evidence that finasteride $(5 \mathrm{mg}$ or $1 \mathrm{mg} /$ die) had an adverse effect on erectile function Similar conclusions were also reached by Canguven and Burnett, [26] and Haber et al. [95]. Anitha et al. [59] found that older uncontrolled studies reported high rates of erectile dysfunction during treatment with finasteride $(0.8-33 \%)$, while randomized controlled trials reported rates of erectile dysfunction between $0.8-15.8 \%$. However, the results of these clinical trials were not considered reliable because they neither assessed baseline sexual function nor used a validated questionnaire. Probably for similar reasons, Erdemir et al. [71] reported high rates of sexual dysfunction with 5-ARIs (between 2.1-38\%); however, they conclude that the rate of erectile dysfunction in clinical trials with 5-ARIs ranges from 5 to $9 \%$. Similar conclusions were also reached by Ponholzer et al. [39]: " $5 \alpha$-reductase inhibitors are associated with ED, loss of libido and decreased ejaculate volume by up to 10\%". Regarding 5ARIs, Gacci et al. [14] found "an overall prevalence of ejaculation disorder equal to $3 \%$, although about 3 times higher than placebo". In a review by Trost et al. [49], slightly higher rates than placebo for reduced libido (1.5\%), erectile dysfunction (1.6\%) and ejaculatory dysfunction (3.4\%) were indicated for 5-ARIs. A recent review by Traish et al. [48] shows slightly different rates of sexual dysfunction. Gur et al. [30] report instead that the true prevalence of sexual side effects with 5-ARI treatment is currently unknown. (D) There have been recent reports of persistent sexual dysfunction after discontinuation of finasteride treatment $[32,56,60,97,99,100,129,131,134,141,147,149,166,170,237]$. Several authors have considered gynecomastia as a sexual dysfunction. This side effect has been reported in a lot of research on 5-ARIs [37,47,49,66,72,76,93,104,115]. 
Table 7. 5-ARI: Rates (minimum and maximum percentages) of sexual dysfunction in double-blind, randomized, placebo-controlled clinical trials for benign prostatic hyperplasia.

\begin{tabular}{ccc}
\hline & Finasteride & Dutasteride \\
\hline ED (Erectile Dysfunction) & $3.4-15.8 \%(1.7-6.3 \%)$ & $1.7-11 \%(1.2-3 \%)$ \\
\hline EjD (Ejaculatory Dysfunction) & $0.2-7.7 \%(0.1-1.7 \%)$ & $0.5-2 \%(0.1-1 \%)$ \\
\hline Decrease in sexual desire & $2.4-13 \%(1.4-2 \%)$ & $0.6-4 \%(0.3-2 \%)$ \\
\hline The effects of placebo are reported in parenthesis. Data by Gur et al. 2013 [30].
\end{tabular}

\section{3. $\alpha$-Blocker and PDE5i Combination}

Several clinical studies seem to confirm that the combination of $\alpha$-blockers and PDE5i is more effective in improving both LUTS and erectile dysfunction than treatment with $\alpha$-blockers alone $[28,186,205,222,226]$. The results from a combination treatment with $\alpha$ blockers and PDE5i in men with ED and BPH suggested a synergistic effect on both erectile dysfunction and LUTS $[23,40,146,177,222]$.

\subsection{PDE5i}

In this review, among the studies on treatment in combination with $\alpha$-blockers or 5ARIs and PDE5i, 17 RCTs were performed on tadalafil [40,192,202-206,208-210,213,215,217$219,221], 3$ RCTs on sildenafil [207,214,216], 2 RCTs on vardenafil [209,222] and 2 RCTs on UK-369.003 [179,212].

PDE5i is used alone or as an add on to $\alpha$-blockers, alfuzosin or tamsulosin, or finasteride [180,203,219]. Oelke et al. [206] reported a significant increase in Qmax ("maximum urinary flow rate", which is the urodynamic parameter for the evaluation of LUTS), even if other studies must be performed to validate this result [169]. The link between erectile dysfunction and LUTS is based on the following four hypotheses: (1) a decrease in or alteration of the endothelial nitroxide synthetase levels in the prostate and in the smooth muscle of the penis; (2) effects related to autonomic hyperactivity; (3) the increased activation of Rho-kinase; (4) pelvic atherosclerosis [33,38,112]. As recently reported, all these mechanisms could be countered by PDE5i [183]. Moreover, PDE5 inhibition has been shown to affect several pathogenic pathways contributing to LUTS, although the exact mechanism of action remains to be elucidated [222]. However, PDE5i use is well tolerated in patients with LUTS and/or BPH (Table 2).

\section{Discussion}

In the present review we found different and apparently conflicting epidemiological data on $\alpha$-blocker- and 5-ARI-induced sexual ADRs (Table 8). Several problems make it difficult to quantify and qualify $\alpha$-blocker- and 5-ARI-induced sexual dysfunction. These problems mainly concern the diagnostic criteria of ejaculatory disorders. None of the reviewed studies used the diagnostic criteria for sexual dysfunction proposed by ICD-10 (WHO, ICD) DSM-IV-TR (American Psychiatric Association, 2000 and DSM5 (American Psychiatric Association, 2013) $[153,164,238]$. Other proposed classifications, such as that of NIH (National Institutes of Health), are rarely used. There is no clear consensus on the classification of "non-premature ejaculatory dysfunction" [152]. There are no clear and shared diagnoses for delayed ejaculation [143]. Previously, Hartmann and Waldinger [138] wrote that "a big problem we should solve is finding consensus on the operational definitions of ejaculatory disorders". As far as we know, the classification of delayed ejaculatory dysfunction is still far from precise. Delayed ejaculation, inadequate ejaculation, inhibited ejaculation, idiopathic ejaculation, (primary) ejaculation and psychogenic ejaculation and psychogenic anejaculation have been used interchangeably to describe a delay or an absence of male orgasmic response [143]. Furthermore, some authors included orgasmic disorders in ejaculatory disorders [139], while others considered ejaculatory dysfunction as orgasm dysfunction [53] due to the lack of consensus on the diagnostic criteria of ejaculatory disorders. We think that it is also important to distinguish anejaculation from retrograde 
ejaculation. Jannini and Lenzi [139] argued that "it is important not to confuse the classification of anejaculation with that of retrograde ejaculation. In the latter case, orgasm is usually present, even if attenuated, while anejaculation always coincides with anorgasmia (even if the opposite is not true)". Hellstrom et al. [21] and Rosen and Seftel [150] defined "severe ejaculatory dysfunction as ejaculation with reduced sperm count or ejaculation loss". Retrograde ejaculation (or dry ejaculation) occurs when semen enters the bladder instead of emerging through the penis [152]. Despite this important difference, many studies do not distinguish between anejaculation and retrograde ejaculation.

Table 8. Summary of the main conclusions on sexual dysfunction in patients treated with $\alpha$-blockers and 5-ARIs (table modified by La Torre et al., 2016) [9].

Tamsulosin is associated with a significantly lower risk of EjD than silodosin (OR: 0.09; $p<0.00001)$ [14]

Alfuzosin, doxazosin and terazosin are associated with a lower risk of EjD compared to a placebo.

Both finasteride and dutasteride have a significantly higher risk of EjD than a placebo.

EjD is significantly more common with combination therapy than with $\alpha$-blockers alone or 5 ARI alone [14].

A-blockers (alfuzosin, doxazosin, tamsulosin, terazosin) show an incidence of decreased libido and erectile dysfunction (ED) very similar to a placebo [72,107].

5-ARIs (finasteride and dutasteride) are associated with an increased risk of erectile dysfunction (ED), ejaculatory dysfunction (EjD) and decreased libido compared to a placebo [72].

The ED rate in 5-ARI clinical trials ranged from 5 to $9 \%$ [71].

The examination of the "post-ejaculate urine semen concentration" serves as a reliable indicator of retrograde ejaculation, but only a few studies considered these data $[87,89,96]$. Other methodological issues include the definition of reduced ejaculatory volume. Numerous physiological factors can cause a reduction in semen volume, e.g., a short period of sexual abstinence ( $<2$ days) or frequent ejaculations before semen collection [167].

In many studies, the abstinence period before semen analysis was not specified. Another possible methodological "bias" is the absence of an objective measurement of semen volume leading to an underestimation of $\mathrm{EjD}$ [87]. A further methodological limitation depends on the lack of definition of the reduction in sperm volume. For example, the WHO indicated that the lower reference limit for semen volume is $1.5 \mathrm{~mL}$, but none of the studies reviewed and reported in this study indicated a reference point for the definition of reduced ejaculate volume, except Hellstrom and Sikka [87], who defined a "decrease in ejaculate volume" as "a greater than $20 \%$ decrease from baseline". The Danish Prostatic Symptom Score (DAN-PSS) is a questionnaire used for the detection of ejaculatory disorders [137]. It includes 12 questions related to voiding problems and the perceived disturbance of each individual symptom and 3 questions related to sexuality (erection, volume of ejaculation, pain/discomfort during ejaculation). This questionnaire has been validated and used in numerous epidemiological surveys and clinical studies $[130,135,137,158]$. However, to the best of our knowledge, the DAN-PSS has only been validated for the evaluation of urinary symptoms and not for sexual function [171]. This could be a potential limitation of the studies using DAN-PSS, as it may have led to an overestimation (or underestimation) of ejaculatory disorders. Rosen and Fitzpatrick [5] reported that the DAN-PSS and ICS questionnaire evaluate only two ejaculatory dysfunctions, i.e., a reduced amount of semen and pain and discomfort during ejaculation. Rosen et al. [3] proposed the use of the MSHQ questionnaire, but few studies used it. As previously pointed out, among the RCTs examined on $\alpha$-blockers and 5-ARIs, only two [82,85] of these used a specific and validated rating scale to measure sexual functioning. In studies that did not use a self-administered questionnaire or that did not directly ask the patient about sexual function, the identification of sexual dysfunction often relies on spontaneous disclosure by patients, but previous research has shown that patients rarely spontaneously report side effects concerning the sexual sphere [140]. Therefore, failure to use the rating scales compromises the true rate 
of sexual dysfunction. Most researchers used the term "libido," which does not indicate which stage (desire, arousal, orgasm) of the human sexual response is affected by sexual dysfunction. Indeed, the term "libido" does not discriminate between the various phases of the sexual response cycle [145]. In the literature, we have found the use of the following, apparently similar, expressions of sexual function, which, however, have probably been interpreted with different meanings: "loss of sexual desire", "Hypoactive Sexual Desire (HSD)", "Hypoactive Sexual Desire Disorder (HSDD)", "Low sexual desire", "reduced sexual desire (libido)", "loss of libido (sexual desire)", "reduced libido". Roehrborn et al. [40] distinguished between "altered (decreased) libido" and "loss of libido", but did not explain the difference between these. Skolarus and Wei, [46] described "erectile function" as defined in terms of (1) "Quality of erection", (2) "Libido/sexual desire" and (3) "Satisfaction". However, defining erectile function in terms of "libido/sexual desire" can be confusing and difficult for the patient to understand.

\section{Conclusions}

Few rigorous studies have been conducted using both control groups and validated questionnaires to evaluate the sexual side effects of $\alpha$-blockers and 5-ARIs [53]. It is desirable that future studies include validated tools to assess and diagnose drug-induced sexual dysfunction, particularly for ejaculation and sexual desire disorder. Failure to use these assessment questionnaires reduces the possibility of detecting the exact incidence of sexual dysfunction and the likelihood of accurately diagnosing the specific type of sexual dysfunction involved, as well as hindering the objective monitoring of the improvement or worsening of symptoms during drug treatment. The MSHQ is a validated questionnaire for the assessment of sexual dysfunction, in particular for the assessment of strength, delay and pleasure in ejaculation $[5,150]$. Other specific rating scales, such as ASEX [142] or CSFQ [154], could also be used for patients with LUTS/BPH. Only a small amount of research has intentionally initiated the study of sexual dysfunction caused by $\alpha$-blockers and 5-ARIs. Therefore, studies that specifically evaluate the sexual dysfunction induced by these drugs are needed. Further studies are needed to determine the pathophysiological mechanisms involved in the link between LUTS and sexual dysfunction (particularly ejaculation disorders) and the optimal management strategies for men with these concomitant conditions $[5,21]$. The sexual side effect profile of these drugs is different. Among the $\alpha$-blockers, silodosin (followed by tamsulosin) shows the highest incidence of ejaculatory disorders. Alfuzosin has no deleterious effects on sexual function and is well tolerated when used in combination with a low dose of PD5i for the treatment of erectile dysfunction. Several authors have documented that the $\alpha$-blocker/PD5i combination may act synergistically to improve both LUTS and sexual function $[23,40,146,222]$. With the exceptions of only silodosin and, to a lesser extent, tamsulosin, the effect of $\alpha$-blockers on sexual function appears similar to a placebo. The sexual adverse event profile of dutasteride appears to be similar to that of finasteride. There have been recent reports of persistent sexual dysfunction after the discontinuation of finasteride treatment, but further studies are required to evaluate a causal relationship [49]. Further studies are also needed to evaluate the long-term role of a combination therapy of PD5i and $\alpha$-blockers or 5-ARIs in LUTS/BPH treatment [184,222]. Several studies show that sexual dysfunction has a high prevalence in sexually active men with LUTS [4], which must be carefully evaluated and diagnosed before treating LUTS, as some treatments may further aggravate it. Despite this, Giona et al. [132] documented that there is a significant discrepancy in the attitude of urologists in advising patients with LUTS-related erectile dysfunction: in particular, a significant minority of urologists do not discuss either erectile dysfunction or ejaculatory disorders with patients before the treatment; moreover, they do not discuss an alternative treatment [132]. The tendency of urologists to not investigate the sex life of patients could negatively affect their quality of life to the extent that effective treatments are not proposed [58]. The importance of both sexological history and clinical evaluation is evident: 
this procedure is essential for the objective monitoring of the improvement or worsening of symptoms during drug treatment.

\section{Patents}

Male sexual dysfunction could be the result of inaccurate sexological history and clinical assessment in patients with urological diseases. In this sense, the evaluation of all drug-related side effects on male sexual function is essential to improve a patients' overall quality of life.

Author Contributions: Conceptualization, A.L.T. and C.P.; methodology, T.C. and I.T.; formal analysis, A.S.; investigation, M.C., V.R. and D.M.; data curation, L.M., A.C., G.M. and G.D.S.; writingoriginal draft preparation, A.L.T.; writing—review and editing, T.C. and L.G.; supervision, L.G. All authors have read and agreed to the published version of the manuscript.

Funding: This research received no external funding.

Institutional Review Board Statement: Not applicable.

Informed Consent Statement: Not applicable.

Data Availability Statement: Not applicable.

Conflicts of Interest: The authors declare no conflict of interest.

\section{References}

1. Nickel, J.C.; Elhilali, M.; Vallancien, G. Benign prostatic hyperplasia (BPH) and prostatitis: Prevalence of painful ejaculation in men with clinical BPH. BJU Int. 2005, 95, 571-574. [CrossRef]

2. Rosen, R.; Altwein, J.; Boyle, P.; Kirby, R.S.; Lukacs, B.; Meuleman, E.; O’Leary, M.P.; Puppo, P.; Robertson, C.; Giuliano, F. Lower Urinary Tract Symptoms and Male Sexual Dysfunction: The Multinational Survey of the Aging Male (MSAM-7). Eur. Urol. 2003, 44, 637-649. [CrossRef]

3. Rosen, R.C.; Catania, J.; Pollack, L.; Althof, S.; O'Leary, M.; Seftel, A.D. Male Sexual Health Questionnaire (MSHQ): Scale development and psychometric validation. Urology 2004, 64, 777-782. [CrossRef] [PubMed]

4. Rosen, R.C.; Wei, J.T.; Althof, S.E.; Seftel, A.D.; Miner, M.; Perelman, M.A. Association of Sexual Dysfunction with Lower Urinary Tract Symptoms of BPH and BPH Medical Therapies: Results from the BPH Registry. Urology 2009, 73, 562-566. [CrossRef] [PubMed]

5. Rosen, R.C.; Fitzpatrick, J.M. Ejaculatory dysfunction in men with lower urinary tract symptoms suggestive of benign prostatic hyperplasia. BJU Int. 2009, 104, 974-983. [CrossRef] [PubMed]

6. Conaglen, H.M.; Conaglen, J.V. Drug-induced sexual dysfunction in men and women. Aust. Prescr. 2013, 36, 42-46. [CrossRef]

7. Tisdale, J.E.; Miller, D.A. Drug-Induced Diseases: Pharmacy and Drug Information Books from ASHP, 3rd ed.; American Society of Health System Pharmacists: Bethesda, MD, USA, 2010.

8. Yang, B.K.; Donatucci, C.F. Drugs That Affect Male Sexual Function. In Male Sexual Function; Humana Press: Totowa, NJ, USA, 2007; pp. 155-193.

9. La Torre, A.; Giupponi, G.; Duffy, D.; Conca, A.; Catanzariti, D. Sexual dysfunction related to drugs: A critical review. Part IV: Cardiovascular drugs. Pharmacopsychiatry 2015, 48, 1-6. [CrossRef] [PubMed]

10. La Torre, A.; Giupponi, G.; Duffy, D.M.; Pompili, M.; Grözinger, M.; Kapfhammer, H.P.; Conca, A. Sexual dysfunction related to psychotropic drugs: A critical review. Part III: Mood stabilizers and anxiolytic drugs. Pharmacopsychiatry 2014, 47, 1-6. [CrossRef] [PubMed]

11. La Torre, A.; Giupponi, G.; Duffy, D.; Conca, A. Sexual dysfunction related to psychotropic drugs: A critical review—Part I: Antidepressants. Pharmacopsychiatry 2013, 46, 191-199. [CrossRef]

12. Rende, P.; Paletta, L.; Gallelli, G.; Raffaele, G.; Natale, V.; Brissa, N.; Costa, C.; Gratteri, S.; Giofrè, C.; Gallelli, L. Retrospective evaluation of adverse drug reactions induced by antihypertensive treatment. J. Pharmacol. Pharmacother. 2013, 4 (Suppl. 1), S47.

13. Carbone, D.J.; Hodges, S. Medical therapy for benign prostatic hyperplasia: Sexual dysfunction and impact on quality of life. Int. J. Impot. Res. 2003, 15, 299-306. [CrossRef] [PubMed]

14. Gacci, M.; Ficarra, V.; Sebastianelli, A.; Corona, G.; Serni, S.; Shariat, S.F.; Maggi, M.; Zattoni, F.; Carini, M.; Novara, G. Impact of medical treatments for male lower urinary tract symptoms due to benign prostatic hyperplasia on ejaculatory function: A systematic review and meta-analysis. J. Sex. Med. 2014, 11, 1554-1566. [CrossRef] [PubMed]

15. Giuliano, F. Medical treatments for benign prostatic hyperplasia and sexual function. BJU Int. 2008, 102 (Suppl. 2), 8-12. [CrossRef]

16. McVary, K.T.; Roehrborn, C.G.; Avins, A.L.; Barry, M.J.; Bruskewitz, R.C.; Donnell, R.F.; Foster, H.E.; Gonzalez, C.M.; Kaplan, S.A.; Penson, D.F.; et al. Update on AUA guideline on the management of benign prostatic hyperplasia. J. Urol. 2011, 185, 1793-1803. [CrossRef] 
17. Miner, M.; Rosenberg, M.T.; Perelman, M.A. Treatment of lower urinary tract symptoms in benign prostatic hyperplasia and its impact on sexual function. Clin. Ther. 2006, 28, 13-25. [CrossRef] [PubMed]

18. Rosen, R.C.; Giuliano, F.; Carson, C.C. Sexual dysfunction and lower urinary tract symptoms (LUTS) associated with benign prostatic hyperplasia (BPH). Eur. Urol. 2005, 47, 824-837. [CrossRef]

19. AUA guideline on management of benign prostatic hyperplasia (2003). Chapter 1: Diagnosis and treatment recommendations. J. Urol. 2003, 170 Pt 1, 530-547. [CrossRef]

20. Kirby, M.; Chapple, C.; Jackson, G.; Eardley, I.; Edwards, D.; Hackett, G.; Ralph, D.; Rees, J.; Speakman, M.; Spinks, J.; et al. Erectile dysfunction and lower urinary tract symptoms: A consensus on the importance of co-diagnosis. Int. J. Clin. Pract. 2013, 67, 606-618. [CrossRef] [PubMed]

21. Hellstrom, W.J.G.; Giuliano, F.; Rosen, R.C. Ejaculatory Dysfunction and Its Association with Lower Urinary Tract Symptoms of Benign Prostatic Hyperplasia and BPH Treatment. Urology 2009, 74, 15-21. [CrossRef]

22. McVary, K. Lower urinary tract symptoms and sexual dysfunction: Epidemiology and pathophysiology. BJU Int. 2006, 97 (Suppl. 2), 23-28. [CrossRef] [PubMed]

23. Gacci, M.; Eardley, I.; Giuliano, F.; Hatzichristou, D.; Kaplan, S.A.; Maggi, M.; McVary, K.T.; Mirone, V.; Porst, H.; Roehrborn, C.G. Critical analysis of the relationship between sexual dysfunctions and lower urinary tract symptoms due to benign prostatic hyperplasia. Eur. Urol. 2011, 60, 809-825. [CrossRef]

24. Taylor, J.M.; Desouza, R.; Wang, R. Common approach to managing lower urinary tract symptoms and erectile dysfunction. Asian J. Androl. 2008, 10, 45-53. [CrossRef]

25. Kaplan, S.A. Side Effects of alpha-Blocker Use: Retrograde Ejaculation. Rev. Urol. 2009, 11 (Suppl. 1), S14-S18.

26. Canguven, O.; Burnett, A.L. The effect of $5 \alpha$-reductase inhibitors on erectile function. J. Androl. 2008, 29, 514-523. [CrossRef]

27. Andriole, G.L.; Kirby, R. Safety and tolerability of the dual $5 \alpha$-reductase inhibitor dutasteride in the treatment of benign prostatic hyperplasia. Eur. Urol. 2003, 44, 82-88. [CrossRef]

28. Giuliano, F. Lower urinary tract symptoms and sexual dysfunction: A common approach. BJU Int. 2008,101 (Suppl. 3), $22-26$. [CrossRef]

29. Giuliano, F.; Droupy, S. La iatrogénie médicamenteuse en médecine sexuelle. Prog. Urol. 2013, 23, 804-810. [CrossRef]

30. Gur, S.; Kadowitz, P.J.; Hellstrom, W.J. Effects of 5-Alpha reductase inhibitors on erectile function, sexual desire and ejaculation. Expert Opin. Drug Saf. 2013, 12, 81-90. [CrossRef] [PubMed]

31. Hwang, T.I.S. Will Medical Management of Benign Prostatic Hyperplasia Result in Better or Worse Sexual Function in Men? Urol. Sci. 2011, 22, 14-18. [CrossRef]

32. Irwig, M.S. Persistent sexual and nonsexual adverse effects of finasteride in younger men. Sex. Med. Rev. 2014, 2, 24-35. [CrossRef] [PubMed]

33. Kaplan, S.A.; De Rose, A.F.; Kirby, R.S.; O'Leary, M.P.; McVary, K.T. Beneficial effects of extendedrelease doxazosin and doxazosin standard on sexual health. BJU Int. 2006, 97, 559-566. [CrossRef] [PubMed]

34. Lee, S.; Lee YBin Choe, S.J.; Lee, W.S. Adverse sexual effects of treatment with finasteride or dutasteride for male androgenetic alopecia: A systematic review and meta-analysis. Acta Derm. Venereol. 2018, 99, 12-17. [CrossRef] [PubMed]

35. Mirone, V.; Sessa, A.; Giuliano, F.; Berges, R.; Kirby, M.; Moncada, I. Current benign prostatic hyperplasia treatment: Impact on sexual function and management of related sexual adverse events. Int. J. Clin. Pract. 2011, 65, 1005-1013. [CrossRef] [PubMed]

36. Mysore, V. Finasteride and sexual side effects. Indian Dermatol. Online J. 2012, 3, 62. [CrossRef]

37. Naslund, M.J.; Miner, M. A review of the clinical efficacy and safety of $5 \alpha$-reductase inhibitors for the enlarged prostate. Clin. Ther. 2007, 29, 17-25. [CrossRef] [PubMed]

38. Orabi, H.; Albersen, M.; Lue, T.F. Association of lower urinary tract symptoms and erectile dysfunction: Pathophysiological aspects and implications for clinical management. Int. J. Impot. Res. 2011, 23, 99-108. [CrossRef] [PubMed]

39. Ponholzer, A.; Madersbacher, S. Lower urinary tract symptoms and erectile dysfunction; Links for diagnosis, management and treatment. Int. J. Impot. Res. 2007, 19, 544-550. [CrossRef] [PubMed]

40. Roehrborn, C.G.; Rosen, R.C. Medical therapy options for aging men with benign prostatic hyperplasia: Focus on alfuzosin 10 mg once daily. Clin. Interv. Aging 2008, 3, 511-524. [CrossRef]

41. Cho, H.J.; Yoo, T.K. Silodosin for the treatment of clinical benign prostatic hyperplasia: Safety, efficacy, and patient acceptability. Res. Rep. Urol. 2014, 6, 113-119.

42. Rosen, R.C. Assessment of sexual dysfunction in patients with benign prostatic hyperplasia. BJU Int. 2006, 97 (Suppl. 2), 29-33. [CrossRef]

43. Rossi, M.; Roumeguère, T. Silodosin in the treatment of benign prostatic hyperplasia. Drug Design Dev. Ther. $2010,4,291-297$.

44. Schiff, J.D.; Mulhall, J.P. The link between LUTS and ED: Clinical and basic science evidence. J. Androl. 2004, 25, 470-478. [CrossRef] [PubMed]

45. Schulman, C.C. Lower urinary tract symptoms/benign prostatic hyperplasia: Minimizing morbidity caused by treatment. Urology 2003, 62 (Suppl. 1), 24-33. [CrossRef]

46. Skolarus, T.A.; Wei, J.T. Measurement of benign prostatic hyperplasia treatment effects on male sexual function. Int. J. Impot. Res. 2009, 21, 267-274. [CrossRef] 
47. Traish, A.M.; Hassani, J.; Guay, A.T.; Zitzmann, M.; Hansen, M.L. Adverse side effects of $5 \alpha$-reductase inhibitors therapy: Persistent diminished libido and erectile dysfunction and depression in a subset of patients. J. Sex. Med. 2011, 8, 872-884. [CrossRef]

48. Traish, A.M.; Mulgaonkar, A.; Giordano, N. The dark side of $5 \alpha$-reductase inhibitors' therapy: Sexual dysfunction, high gleason grade prostate cancer and depression. Korean J. Urol. 2014, 55, 367-379. [CrossRef]

49. Trost, L.; Saitz, T.R.; Hellstrom, W.J.G. Side effects of 5-alpha reductase inhibitors: A comprehensive review. Sex. Med. Rev. 2013, 1, 24-41. [CrossRef]

50. Van Dijk, M.M.; De La Rosette, J.J.M.C.H.; Michel, M.C. Effects of $\alpha 1$-adrenoceptor antagonists on male sexual function. Drugs 2006, 66, 287-301. [CrossRef]

51. De Nunzio, C.; Roehrborn, C.G.; Andersson, K.E.; McVary, K.T. Erectile Dysfunction and Lower Urinary Tract Symptoms. Eur. Urol. Focus 2017, 3, 352-363. [CrossRef] [PubMed]

52. Van Moorselaar, J. LUTS Sexual Dysfunction: Implications for Management of BPH. Eur. Urol. Suppl. 2003, 2, 13-20. [CrossRef]

53. Welliver, C.; Butcher, M.; Potini, Y.; McVary, K.T. Impact of alpha blockers, 5-alpha reductase inhibitors and combination therapy on sexual function topical collection on benign prostatic hyperplasia. Curr. Urol. Rep. 2014, 15, 441. [CrossRef]

54. Wiser, H.J.; Köhler, T.S. Sexual impact of treatment of lower urinary tract symptoms associated with benign prostatic hyperplasia. Curr. Urol. Rep. 2010, 11, 228-235. [CrossRef]

55. Wu, X.J.; Zhi, Y.; Zheng, J.; He, P.; Zhou, X.Z.; Li, W.B.; Zhou, Z.S. Dutasteride on benign prostatic hyperplasia: A meta-analysis on randomized clinical trials in 6460 patients. Urology 2014, 83, 539-543. [CrossRef]

56. Yassin, A.; Saad, F.; Hoesl, C.E.; Traish, A.M.; Hammadeh, M.; Shabsigh, R. Alpha-adrenoceptors are a common denominator in the pathophysiology of erectile function and BPH/LUTS-Implications for clinical practice. Andrologia 2006, 38, 1-12. [CrossRef] [PubMed]

57. Yoshida, M.; Kudoh, J.; Homma, Y.; Kawabe, K. Safety and efficacy of silodosin for the treatment of benign prostatic hyperplasia. Clin. Interv. Aging 2011, 6, 161-172. [CrossRef] [PubMed]

58. Zhao, H.; Kim, H.H. The Complex Relationship between Lower Urinary Tract Symptoms and Sexual Health. Curr. Urol. Rep. 2019, 20, 58. [CrossRef] [PubMed]

59. Inamadar, A.; Ragunatha, S.; Anitha, B. Finasteride-its impact on sexual function and prostate cancer. J. Cutan Aesthet. Surg. 2009, 2, 12. [CrossRef]

60. Baas, W.R.; Butcher, M.J.; Lwin, A.; Holland, B.; Herberts, M.; Clemons, J.; Delfino, K.; Althof, S.; Kohler, T.S.; McVary, K.T. A Review of the FAERS Data on 5-Alpha Reductase Inhibitors: Implications for Postfinasteride Syndrome. Urology 2018, 120, 143-149. [CrossRef]

61. Roehrborn, C.G.; Siami, P.; Barkin, J.; Damião, R.; Major-Walker, K.; Morrill, B.; Montorsi, F. The effects of dutasteride, tamsulosin and combination therapy on lower urinary tract symptoms in men with benign prostatic hyperplasia and prostatic enlargement: 2-year results from the CombAT study. J. Urol. 2008, 179, 616-621. [CrossRef]

62. Ding, H.; Du, W.; Hou, Z.Z.; Wang, H.Z.; Wang, Z.P. Silodosin is effective for treatment of LUTS in men with BPH: A systematic review. Asian J. Androl. 2013, 15, 121-128. [CrossRef]

63. Barkin, J. Benign prostatic hyperplasia and lower urinary tract symptoms: Evidence and approaches for best case management. Can. J. Urol. 2011, 18, 14

64. Chung, B.H.; Lee, J.Y.; Kim, C.I.; Kim, C.S.; Oh, C.Y.; Lee, S.W.; Lee, J.S.; Yoo, S.J. Sexuality and the management of BPH with alfuzosin (SAMBA) trial. Int. J. Impot. Res. 2009, 21, 68-73. [CrossRef]

65. Lowe, F.C. Treatment of lower urinary tract symptoms suggestive of benign prostatic hyperplasia: Sexual function. BJU Int. 2005, 95, 12-18. [CrossRef] [PubMed]

66. Marihart, S.; Harik, M.; Djavan, B. Dutasteride: A review of current data on a novel dual inhibitor of 5alpha reductase. Rev. Urol. 2005, 7, 203-210. [PubMed]

67. Wolters, J.P.; Hellstrom, W.J.G. Current concepts in ejaculatory dysfunction. Rev. Urol. 2006, 8 (Suppl. 4), S18-S25. [PubMed]

68. Lepor, H. Medical treatment of benign prostatic hyperplasia. Rev. Urol. 2011, 13, 20-33.

69. Wu, W.-J.; Liu, C.-C.; Huang, S.-P.; Lee, Y.-C.; Wang, C.-J.; Chou, Y.-H.; Huang, C.-H. Selecting an Appropriate $\alpha 1-$ Adrenoceptor Blocker in the Treatment of Lower Urinary Tract Symptoms Associated with Benign Prostatic Hyperplasia. Incont Pelvic Floor Dysfunct 2009, 3, 73-76.

70. Lampros, M. Relationship between Therapy with A1-Adrenoceptor Antagonists (A1-Blockers) for Benign Prostatic Obstruction and Sexual Function. J. Urol. Nephrol. 2014, 1, 5. [CrossRef]

71. Erdemir, F.; Harbin, A.; Hellstrom, W.J.G. 5-alpha reductase inhibitors and erectile dysfunction: The connection. J. Sex. Med. 2008, 5, 2917-2924. [CrossRef]

72. Giuliano, F. Impact of medical treatments for benign prostatic hyperplasia on sexual function. BJU Int. 2006, 97 (Suppl. 2), 34-38 [CrossRef]

73. Chapple, C.R.; Montorsi, F.; Tammela, T.L.J.; Wirth, M.; Koldewijn, E.; Fernández Fernández, E. Silodosin therapy for lower urinary tract symptoms in men with suspected benign prostatic hyperplasia: Results of an international, randomized, double-blind, placebo- and active-controlled clinical trial performed in Europe. Eur. Urol. 2011, 59, 342-352. [CrossRef] 
74. Choo, M.S.; Song, M.; Kim, J.H.; Lee, K.S.; Kim, J.C.; Kim, S.W.; Yang, S.K.; Lee, J.G.; Lee, J.Z.; Kim, D.K.; et al. Safety and efficacy of 8-mg once-daily vs. 4-mg twice-daily silodosin in patients with lower urinary tract symptoms suggestive of benign prostatic hyperplasia (silver study): A 12-week, double-blind, randomized, parallel, multicenter study. Urology 2014, 83, 875-881. [CrossRef] [PubMed]

75. Nordling, J. Efficacy and safety of two doses $(10$ and $15 \mathrm{mg})$ of alfuzosin or tamsulosin $(0.4 \mathrm{mg})$ once daily for treating symptomatic benign prostatic hyperplasia. BJU Int. 2005, 95, 1006-1012. [CrossRef] [PubMed]

76. Roehrborn, C.G.; Marks, L.S.; Fenter, T.; Freedman, S.; Tuttle, J.; Gittleman, M.; Morrill, B.; Wolford, E.T. Efficacy and safety of dutasteride in the four-year treatment of men with benign prostatic hyperplasia. Urology 2004, 63, 709-715. [CrossRef] [PubMed]

77. Kirby, R.S.; Roehrborn, C.; Boyle, P.; Bartsch, G.; Jardin, A.; Cary, M.M.; Sweeney, M.; Grossman, E.B. Efficacy and tolerability of doxazosin and finasteride, alone or in combination, in treatment of symptomatic benign prostatic hyperplasia: The Prospective European Doxazosin and Combination Therapy (PREDICT) trial. Urology 2003, 61, 119-126. [CrossRef]

78. Roehrborn, C.G.; McVary, K.T.; Elion-Mboussa, A.; Viktrup, L. Tadalafil Administered Once Daily for Lower Urinary Tract Symptoms Secondary to Benign Prostatic Hyperplasia: A Dose Finding Study. J. Urol. 2008, 180, 1228-1234. [CrossRef]

79. Rosen, R.; Seftel, A.; Roehrborn, C.G. Effects of alfuzosin $10 \mathrm{mg}$ once daily on sexual function in men treated for symptomatic benign prostatic hyperplasia. Int. J. Impot. Res. 2007, 19, 480-485. [CrossRef] [PubMed]

80. Shimizu, F.; Taguri, M.; Harada, Y.; Matsuyama, Y.; Sase, K.; Fujime, M. Impact of dry ejaculation caused by highly selective $\alpha 1$ a-blocker: Randomized, double-blind, placebo-controlled crossover pilot study in healthy volunteer men. J. Sex. Med. 2010, 7, 1277-1283. [CrossRef] [PubMed]

81. Wessells, H.; Roy, J.; Bannow, J.; Grayhack, J.; Matsumoto, A.M.; Tenover, L.; Herlihy, R.; Fitch, W.; Labasky, R.; Auerbach, S.; et al. Incidence and severity of sexual adverse experiences in finasteride and placebo-treated men with benign prostatic hyperplasia. Urology 2003, 61, 579-584. [CrossRef]

82. Yokoyama, T.; Hara, R.; Fukumoto, K.; Fujii, T.; Jo, Y.; Miyaji, Y.; Nagai, A.; Sone, A. Effects of three types of alpha-1 adrenoceptor blocker on lower urinary tract symptoms and sexual function in males with benign prostatic hyperplasia. Int. J. Urol. 2011, 18, 225-230. [CrossRef]

83. Yu, H.J.; Lin, A.T.L.; Yang, S.S.D.; Tsui, K.H.; Wu, H.C.; Cheng, C.L.; Cheng, H.L.; Wu, T.T.; Chiang, P.H. Non-inferiority of silodosin to tamsulosin in treating patients with lower urinary tract symptoms (LUTS) associated with benign prostatic hyperplasia (BPH). BJU Int. 2011, 108, 1843-1848. [CrossRef]

84. Roehrborn, C.G.; Siami, P.; Barkin, J.; Damião, R.; Major-Walker, K.; Nandy, I.; Morrill, B.B.; Gagnier, R.P.; Montorsi, F. The Effects of Combination Therapy with Dutasteride and Tamsulosin on Clinical Outcomes in Men with Symptomatic Benign Prostatic Hyperplasia: 4-Year Results from the CombAT Study. Eur. Urol. 2010, 57, 123-131. [CrossRef]

85. Fwu, C.W.; Eggers, P.W.; Kirkali, Z.; McVary, K.T.; Burrows, P.K.; Kusek, J.W. Change in sexual function in men with lower urinary tract symptoms/benign prostatic hyperplasia associated with long-term treatment with doxazosin, finasteride and combined therapy. J. Urol. 2014, 191, 1828-1834. [CrossRef]

86. Roehrborn, C.G.; Van Kerrebroeck, P.; Nordling, J. Safety and efficacy of alfuzosin 10 mg once-daily in the treatment of lower urinary tract symptoms and clinical benign prostatic hyperplasia: A pooled analysis of three double-blind, placebo-controlled studies. BJU Int. 2003, 92, 257-261. [CrossRef]

87. Hellstrom, W.J.G.; Sikka, S.C. Effects of Acute Treatment with Tamsulosin Versus Alfuzosin on Ejaculatory Function in Normal Volunteers. J. Urol. 2006, 176, 1529-1533. [CrossRef]

88. Kawabe, K.; Yoshida, M.; Homma, Y. Silodosin, a new $\alpha 1 \mathrm{~A}$-adrenoceptor-selective antagonist for treating benign prostatic hyperplasia: Results of a phase III randomized, placebo-controlled, double-blind study in Japanese men. BJU Int. 2006, 98, 1019-1024. [CrossRef]

89. Kobayashi, K.; Masumori, N.; Kato, R.; Hisasue, S.; Furuya, R.; Tsukamoto, T. Orgasm is preserved regardless of ejaculatory dysfunction with selective $\alpha 1 \mathrm{~A}$-blocker administration. Int. J. Impot. Res. 2009, 21, 306-310. [CrossRef]

90. Lapitan, M.C.M.; Acepcion, V.; Mangubat, J. A comparative study on the safety and efficacy of tamsulosin and alfuzosin in the management of symptomatic benign prostatic hyperplasia: A randomized controlled clinical trial. J. Int. Med. Res. 2005, 33, 562-573. [CrossRef] [PubMed]

91. Marks, L.S.; Gittelman, M.C.; Hill, L.A.; Volinn, W.; Hoel, G. Rapid efficacy of the highly selective $\alpha 1$ A-adrenoceptor antagonist silodosin in men with signs and symptoms of benign prostatic hyperplasia: Pooled results of 2 phase 3 studies. J. Urol. 2013, 189 (Suppl. 1), S122-S128. [CrossRef] [PubMed]

92. McConnell, J.D.; Roehrborn, C.G.; Bautista, O.M.; Andriole, G.L.; Dixon, C.M.; Kusek, J.W.; Lepor, H.; McVary, K.T.; Nyberg, L.M.; Clarke, H.S.; et al. The Long-Term Effect of Doxazosin, Finasteride, and Combination Therapy on the Clinical Progression of Benign Prostatic Hyperplasia. N. Engl. J. Med. 2003, 349, 2387-2398. [CrossRef] [PubMed]

93. Na, Y.; Ye, Z.; Zhang, S. Efficacy and safety of dutasteride in Chinese adults with symptomatic benign prostatic hyperplasia: A randomized, double-blind, parallel-group, placebo-controlled study with an open-label extension. Clin. Drug Investig. 2012, 32, 29-39. [CrossRef]

94. Gomes, C.M.; Averbeck, M.A.; Koyama, M.; Soler, R. Association among Lower Urinary Tract Symptoms, Erectile Function, and Sexual Satisfaction: Results from the Brazil LUTS Study. Sex. Med. 2020, 8, 45-56. [CrossRef] 
95. Haber, R.S.; Gupta, A.K.; Epstein, E.; Carviel, J.L.; Foley, K.A. Finasteride for androgenetic alopecia is not associated with sexual dysfunction: A survey-based, single-centre, controlled study. J. Eur. Acad. Dermatol. Venereol. 2019, 33, 1393-1397. [CrossRef] [PubMed]

96. Hisasue, S.I.; Furuya, R.; Itoh, N.; Kobayashi, K.; Furuya, S.; Tsukamoto, T. Ejaculatory disorder caused by alpha-1 adrenoceptor antagonists is not retrograde ejaculation but a loss of seminal emission. Int. J. Urol. 2006, 13, 1311-1316. [CrossRef] [PubMed]

97. Hogan, C.; Le Noury, J.; Healy, D.; Mangin, D. One hundred and twenty cases of enduring sexual dysfunction following treatment. Int. J. Risk Saf. Med. 2014, 26, 109-116. [CrossRef] [PubMed]

98. Huang, W.J.; Chen, K.K.; Chang, L.S. Correlation between voiding and erectile function in patients with symptomatic benign prostatic hyperplasia. J. Chin. Med. Assoc. 2005, 68, 178-182. [CrossRef]

99. Irwig, M.S.; Kolukula, S. Persistent Sexual Side Effects of Finasteride for Male Pattern Hair Loss. J. Sex. Med. 2011, 8, 1747-1753. [CrossRef] [PubMed]

100. Irwig, M.S. Persistent Sexual Side Effects of Finasteride: Could They Be Permanent? J. Sex. Med. 2012, 9, 2927-2932. [CrossRef] [PubMed]

101. Jo, H.W.; Yoo, D.S.; Ju, H.T.; Whang, H.W.; Park, J.; Kim, E.T.; Kim, D.K.; Woo, S.H. Effect of patient-optimized doses of tamsulosin on erectile function in men with erectile dysfunction and lower urinary tract symptoms. Korean J. Urol. 2013, 54, 100-105. [CrossRef]

102. Jung, J.H.; Jae, S.U.; Kam, S.C.; Hyun, J.S. Correlation between lower urinary tract symptoms (LUTS) and sexual function in benign prostatic hyperplasia: Impact of treatment of LUTS on sexual function. J. Sex. Med. 2009, 6, 2299-2304. [CrossRef]

103. Barqawi, A.B.; Myers, J.B.; O'Donnell, C.; Crawford, E.D. The effect of $\alpha$-blocker and $5 \alpha$-reductase inhibitor intake on sexual health in men with lower urinary tract symptoms. BJU Int. 2007, 100, 853-857. [CrossRef] [PubMed]

104. Kaplan, S.A.; Chung, D.E.; Lee, R.K.; Scofield, S.; Te, A.E. A 5-year retrospective analysis of $5 \alpha$-reductase inhibitors in men with benign prostatic hyperplasia: Finasteride has comparable urinary symptom efficacy and prostate volume reduction, but less sexual side effects and breast complications than dutasteride. Int. J. Clin. Pract. 2012, 66, 1052-1055. [CrossRef]

105. Kirby, R.S.; O'Leary, M.P.; Carson, C. Efficacy of extended-release doxazosin and doxazosin standard in patients with concomitant benign prostatic hyperplasia and sexual dysfunction. BJU Int. 2005, 95, 103-109. [CrossRef]

106. Kobayashi, K.; Masumori, N.; Hisasue, S.I.; Kato, R.; Hashimoto, K.; Itoh, N.; Tsukamoto, T. Inhibition of seminal emission Is the main cause of anejaculation induced by a new highly selective $\alpha 1$ A-Blocker in normal volunteers. J. Sex. Med. 2008, 5, 2185-2190. [CrossRef] [PubMed]

107. Kumar, R.; Nehra, A.; Jacobson, D.J.; McGree, M.E.; Gades, N.M.; Lieber, M.M.; Jacobsen, S.J.; St Sauver, J.L. $\alpha$-Blocker Use Is Associated with Decreased Risk of Sexual Dysfunction. Urology 2009, 74, 82-87. [CrossRef]

108. Leliefeld, H.H.J.; Stoevelaar, H.J.; McDonnell, J. Sexual function before and after various treatments for symptomatic benign prostatic hyperplasia. BJU Int. 2002, 89, 208-213. [CrossRef] [PubMed]

109. Li, M.K.; Garcia, L.A.; Rosen, R. Lower urinary tract symptoms and male sexual dysfunction in Asia: A survey of ageing men from five Asian countries. BJU Int. 2005, 96, 1339-1354. [CrossRef] [PubMed]

110. Nagai, A.; Hara, R.; Yokoyama, T.; Jo, Y.; Fujii, T.; Miyaji, Y. Ejaculatory dysfunction caused by the new $\alpha 1$-blocker silodosin: A preliminary study to analyze human ejaculation using color Doppler ultrasonography. Int. J. Urol. 2008, 15, 915-918. [CrossRef] [PubMed]

111. Permpongkosol, S.; Krilad-O-Larn, S.; Ratana-O-Larn, K. Treatment with a Uroselective $\alpha 1$-Blocker Improves Voiding and Sexual Function: A Study in Thai Men with Lower Urinary Tract Symptoms. J. Sex. Med. 2011, 8, 2582-2589. [CrossRef]

112. Roehrborn, C.G.; Kaplan, S.A.; Lepor, H.; Volinn, W. Symptomatic and urodynamic responses in patients with reduced or no seminal emission during silodosin treatment for LUTS and BPH. Prostate Cancer Prostatic Dis. 2011, 14, 143-148. [CrossRef]

113. Capogrosso, P.; Serino, A.; Ventimiglia, E.; Boeri, L.; Dehò, F.; Damiano, R.; Briganti, A.; Montorsi, F.; Salonia, A. Effects of silodosin on sexual function-Realistic picture from the everyday clinical practice. Andrology 2015, 3, 1076-1081. [CrossRef] [PubMed]

114. Sakata, K.; Morita, T. Investigation of ejaculatory disorder by silodosin in the treatment of prostatic hyperplasia. BMC Urol. 2012, 12, 29. [CrossRef] [PubMed]

115. Schulman, C.; Pommerville, P.; Höfner, K.; Wachs, B. Long-term therapy with the dual $5 \alpha$-reductase inhibitor dutasteride is well tolerated in men with symptomatic benign prostatic hyperplasia. BJU Int. 2006, 97, 73-80. [CrossRef] [PubMed]

116. Shelbaia, A.; Elsaied, W.M.; Elghamrawy, H.; Abdullah, A.; Salaheldin, M. Effect of selective alpha-blocker tamsulosin on erectile function in patients with lower urinary tract symptoms due to benign prostatic hyperplasia. Urology 2013, 82, 130-135. [CrossRef]

117. Song, S.H.; Son, H.; Kim, K.T.; Kim, S.W.; Moon, D.G.; Moon, K.H.; Park, K.; Park, J.K.; Lee, S.W.; Hyun, J.S.; et al. Effect of tamsulosin on ejaculatory function in BPH/LUTS. Asian J. Androl. 2011, 13, 846-850. [CrossRef]

118. Vallancien, G.; Emberton, M.; Alcaraz, A.; Matzkin, H.; Van Moorselaar, R.J.A.; Hartung, R.; Harving, N.; Elhilali, M. Alfuzosin 10 mg once daily for treating benign prostatic hyperplasia: A 3-year experience in real-life practice. BJU Int. 2008, 101, 847-852. [CrossRef] [PubMed]

119. Van Moorselaar, R.J.A.; Hartung, R.; Emberton, M.; Harving, N.; Matzkin, H.; Elhilali, M.; Alcaraz, A.; Vallancien, G. Alfuzosin 10 $\mathrm{mg}$ once daily improves sexual function in men with lower urinary tract symptoms and concomitant sexual dysfunction. BJU Int. 2005, 95, 603-608. [CrossRef] [PubMed] 
120. Yoshimura, K.; Sakaeda, T.; Kadoyama, K.; Sugino, Y.; Ogawa, O.; Okuno, Y. A survey of the FAERS database concerning the adverse event profiles of $\alpha 1$-adrenoreceptor blockers for lower urinary tract symptoms. Int. J. Med. Sci. 2013, 10, 864-869. [CrossRef]

121. Kim, S.W.; Lee, W.C.; Kim, M.T.; Ko, K.; Lee, W.K.; Lee, C.H.; Kim, J.J.; Yang, D.Y. Effects of low-dose tamsulosin on sexual function in patients with lower urinary tract symptoms suggestive of benign prostatic hyperplasia. Korean J. Urol. 2013, 54, 697-702. [CrossRef]

122. Elhilali, M.; Emberton, M.; Matzkin, H.; Van Moorselaar, R.J.A.; Hartung, R.; Harving, N.; Alcaraz, A.; Vallancien, G. Long-term efficacy and safety of alfuzosin $10 \mathrm{mg}$ once daily: A 2-year experience in "real-life" practice. BJU Int. 2006, 97, 513-519. [CrossRef]

123. Chi, B.H.; Kim, S.C. Changes in Sexual Function in benign prostatic hyperplasia Patients Taking Dutasteride: 1-year follow-up results. Korean J. Urol. 2011, 52, 632-636. [CrossRef]

124. Rosen, R.; Altwein, J.; Boyle, P.; Kirby, R.S.; Lukacs, B.; Meuleman, E.; O’Leary, M.P.; Puppo, P.; Robertson, C.; Giuliano, F. Troubles urinaires du bas appareil et dysfonction sexuelle masculine: L'Enquête MSAM-7 ou Enquête Multinationale de l'Homme Agé. Prog. Urol. 2004, 14, 332-344.

125. Corona, G.; Rastrelli, G.; Maseroli, E.; Balercia, G.; Sforza, A.; Forti, G.; Mannucci, E.; Maggi, M. Inhibitors of $5 \alpha$-reductase-related side effects in patients seeking medical care for sexual dysfunction. J. Endocrinol. Investig. 2012, 35, 915-920.

126. De Rose, A.F.; Giglio, M.; Traverso, P.; Lantieri, P.; Carmignani, G. Combined oral therapy with sildenafil and doxazosin for the treament of non-organic erectile dysfunction refractory to sildenafil monotherapy. Int. J. Impot. Res. 2002, 14, 50-53. [CrossRef] [PubMed]

127. Demir, O.; Ozdemir, I.; Bozkurt, O.; Aslan, G.; Esen, A.A. The effect of $\alpha$-blocker therapy on erectile functions in patients with lower urinary tract symptoms due to benign prostate hyperplasia. Asian J. Androl. 2009, 11, 716-722. [CrossRef] [PubMed]

128. Nickel, J.C.; Elhilali, M.; Emberton, M.; Vallancien, G. The beneficial effect of alfuzosin $10 \mathrm{mg}$ once daily in "real-life" practice on lower urinary tract symptoms (LUTS), quality of life and sexual dysfunction in men with LUTS and painful ejaculation. BJU Int. 2006, 97, 1242-1246. [CrossRef] [PubMed]

129. Ganzer, C.A.; Jacobs, A.R.; Iqbal, F. Persistent Sexual, Emotional, and Cognitive Impairment Post-Finasteride: A Survey of Men Reporting Symptoms. Am. J. Mens Health 2015, 9, 222-228. [CrossRef]

130. Engström, G.; Walker-Engström, M.L.; Henningsohn, L.; Lööf, L.; Leppert, J. Prevalence of distress and symptom severity from the lower urinary tract in men: A population-based study with the DAN-PSS questionnaire. Fam. Pract. 2004, 21, 617-622. [CrossRef]

131. Giatti, S.; Diviccaro, S.; Panzica, G.; Melcangi, R.C. Post-finasteride syndrome and post-SSRI sexual dysfunction: Two sides of the same coin? Endocrine 2018, 61, 180-193. [CrossRef]

132. Giona, S.; Ganguly, I.; Muir, G. Urologists' attitudes to sexual complications of LUTS/BPH treatments. World J. Urol. 2018, 36, 1449-1453. [CrossRef]

133. Goldstein, I. An old problem with a new cause-5 alpha reductase inhibitors and persistent sexual dysfunction. J. Sex. Med. 2011, 8, 1829-1831. [CrossRef]

134. Gray, S.L.; Semla, T.P. Post-finasteride syndrome. BMJ 2019, 366. [CrossRef] [PubMed]

135. Häkkinen, J.T.; Hakama, M.; Huhtala, H.; Shiri, R.; Auvinen, A.; Tammela, T.L.J.; Koskimäki, J. Impact of LUTS Using Bother Index in DAN-PSS-1 Questionnaire. Eur. Urol. 2007, 51, 473-478. [CrossRef]

136. Meyhoff, H.H.; Hald, T.; Nordling, J.; Andersen, J.T.; Bilde, T.; Walter, S. A new patient weighted symptom score system (DAN-PSS-1): Clinical assessment of indications and outcomes of transurethral prostatectomy for uncomplicated benign prostatic hyperplasia. Scand. J. Urol. Nephrol. 1993, 27, 493-499. [CrossRef] [PubMed]

137. Hansen, B.J.; Flyger, H.; Brasso, K.; Schou, J.; Nordling, J.; Andersen, J.T.; Mortensenm, S.; Meyhoff, H.-H.; Walter, S.; Hald, T. Validation of the self-administered Danish Prostatic Symptom Score (DAN-PSS-1) system for use in benign prostatic hyperplasia. Br. J. Urol. 1995, 76, 451-458. [CrossRef]

138. Hartmann, U.; Waldinger, M.D. Ejaculatory disorders. World J. Urol. 2005, 23, 67. [CrossRef] [PubMed]

139. Jannini, E.A.; Lenzi, A. Ejaculatory disorders: Epidemiology and current approaches to definition, classification and subtyping. World J. Urol. 2005, 23, 68-75. [CrossRef]

140. Basson, R.; Rees, P.; Wang, R.; Montejo, A.L.; Incrocci, L. Sexual function in chronic illness. J. Sex. Med. 2010, 7 Pt 2, $374-388$. [CrossRef]

141. Maksym, R.B.; Kajdy, A.; Rabijewski, M. Post-finasteride syndrome-does it really exist? Aging Male 2019, 22, $250-259$.

142. McGahuey, C.A.; Gelenberg, A.J.; Laukes, C.A.; Moreno, F.A.; Delgado, P.L.; McKnight, K.M.; Manber, R. The arizona sexual experience scale (Asex): Reliability and validity. J. Sex. Marital. Ther. 2000, 26, 25-38.

143. Mcmahon, C.G.; Jannini, E.; Waldinger, M.; Rowland, D. Standard Operating Procedures in the Disorders of Orgasm and Ejaculation. J. Sex. Med. 2013, 10, 204-229. [CrossRef]

144. Mondaini, N.; Gontero, P.; Giubilei, G.; Lombardi, G.; Cai, T.; Gavazzi, A.; Bartoletti, R. Finasteride 5 mg and sexual side effects: How many of these are related to a Nocebo phenomenon? J. Sex. Med. 2007, 4, 1708-1712. [CrossRef]

145. Montgomery, S.A.; Baldwin, D.S.; Riley, A. Antidepressant medications: A review of the evidence for drug-induced sexual dysfunction. J. Affect. Disord. 2002, 69, 119-140. [CrossRef] 
146. Oelke, M.; Bachmann, A.; Descazeaud, A.; Emberton, M.; Gravas, S.; Michel, M.C.; N’Dow, J.; Nordling, J.; De La Rosette, J.J. EAU guidelines on the treatment and follow-up of non-neurogenic male lower urinary tract symptoms including benign prostatic obstruction. Eur. Urol. 2013, 64, 118-140. [CrossRef]

147. Pereira, A.F.J.R.; de Coelho, T.O.A. Post-finasteride syndrome. An. Bras. Dermatol. 2020, 95, 271-277. [CrossRef] [PubMed]

148. Petrone, L.; Mannucci, E.; Corona, G.; Bartolini, M.; Forti, G.; Giommi, R.; Maggi, M. Structured interview on erectile dysfunction (SIEDY(): A new, multidimensional instrument for quantification of pathogenetic issues on erectile dysfunction. Int. J. Impot. Res. 2003, 15, 210-220. [CrossRef]

149. Borgo, F.; Macandog, A.D.; Diviccaro, S.; Falvo, E.; Giatti, S.; Cavaletti, G.; Melcangi, R.C. Alterations of gut microbiota composition in post-finasteride patients: A pilot study. J. Endocrinol. Investig. 2021, 44, 1263-1273. [CrossRef] [PubMed]

150. Rosen, R.C.; Seftel, A.D. Validated questionnaires for assessing sexual dysfunction and BPH/LUTS: Solidifying the common pathophysiologic link. Int. J. Impot. Res. 2008, 20 (Suppl. 3), S27-S32. [CrossRef]

151. Sciarra, A. Lower Urinary Tract Symptoms (LUTS) and Sexual Dysfunction (SD): New Targets for New Combination Therapies? Eur. Urol. 2007, 51, 1485-1487. [CrossRef] [PubMed]

152. Seyam, R. A systematic review of the correlates and management of nonpremature ejaculatory dysfunction in heterosexual men. Ther. Adv. Urol. 2013, 5, 254-297. [CrossRef] [PubMed]

153. American Psychiatric Association. Diagnostic and Statistical Manual of Mental Disorders; American Psychiatric Association: Washington, DC, USA, 2013.

154. Clayton, A.H.; McGarvey, E.L.; Clavet, G.J.; Piazza, L. Comparison of sexual functioning in clinical and nonclinical populations using the changes in sexual functioning questionnaire (CSFQ). Psychopharmacol. Bull. 1997, 33, 747.

155. Montejo, A.L.; Llorca, G.; Izquierdo, J.A.; Rico-Villademoros, F. Incidence of sexual dysfunction associated with antidepressant agents: A prospective multicenter study of 1022 outpatients. J. Clin. Psychiatry 2001, 62 (Suppl. 3), 10-21.

156. La Torre, A.; Conca, A.; Duffy, D.; Giupponi, G.; Pompili, M.; Grözinger, M. Sexual dysfunction related to psychotropic drugs: A critical review part II: Antipsychotics. Pharmacopsychiatry 2013, 46, 201-208. [CrossRef]

157. Rowland, D.; McMahon, C.G.; Abdo, C.; Chen, J.; Jannini, E.; Waldinger, M.D.; Ahn, T.Y. Disorders of orgasm and ejaculation in men. J. Sex. Med. 2010, 7 Pt 2, 1668-1686. [CrossRef]

158. Brasso, K.; Stigsby, B.; Pilsgård, B.; Nordling, J. Recision of a patient-weighted symptom score in prostatism: The dan-pss-1 questionnaire. Scand. J. Urol. Nephrol. 1994, 28, 71-75. [CrossRef] [PubMed]

159. Morgia, G. Does the use of silodosin to treat benign prostatic hyperplasia really offer something new? Eur. Urol. 2011, 59, 353-355. [CrossRef] [PubMed]

160. Mykletun, A.; Dahl, A.A.; O'Leary, M.P.; Fosså, S.D. Assessment of male sexual function by the Brief Sexual Function Inventory. BJU Int. 2006, 97, 316-323. [CrossRef] [PubMed]

161. Rosen, R.C.; Catania, J.A.; Althof, S.E.; Pollack, L.M.; O’Leary, M.; Seftel, A.D.; Coon, D.W. Development and Validation of Four-Item Version of Male Sexual Health Questionnaire to Assess Ejaculatory Dysfunction. Urology 2007, 69, 805-809. [CrossRef]

162. Schou, J.; Holm, N.R.; Meyhoff, H.H. Sexual function in patients with symptomatic benign prostatic hyperplasia. Scand. J. Urol. Nephrol. 1996, 30, 119-122.

163. Vallancien, G.; Emberton, M.; Harving, N.; Van Moorselaar, R.J.A. Sexual dysfunction in 1274 European men suffering from lower urinary tract symptoms. J. Urol. 2003, 169, 2257-2261. [CrossRef] [PubMed]

164. American Psychiatric Association. Diagnostic and Statistical Manual of Mental Disorders, 5th ed.; Text Revision (DSM-IV-TR); American Psychiatric Association: Washington, DC, USA, 2000.

165. World Health Organization. International Classification of Diseases and Related Health Problems; 10th Revision; World Health Organization: Geneva, Switzerland, 2007.

166. Canguven, O.; Talib, R.A. Persistent Sexual Side Effects of Finasteride: Could They Be Permanent? J. Sex. Med. 2013, $10,1441$. [CrossRef]

167. World Health Organization. WHO Laboratory Manual for the Examination and Processing of Human Semen; World Health Organization: Geneva, Switzerland, 2010.

168. NIH Impotence: NIH Consensus Development Panel on Impotence. JAMA 1993, 270, 83-90. [CrossRef]

169. Chapple, C.R. Monotherapy with $\alpha$-blocker or phosphodiesterase 5 inhibitor for lower urinary tract symptoms? Eur. Urol. 2012, 61, 926-927. [CrossRef] [PubMed]

170. Diviccaro, S.; Melcangi, R.C.; Giatti, S. Post-finasteride syndrome: An emerging clinical problem. Neurobiol. Stress 2020, $12,100209$. [CrossRef] [PubMed]

171. Donovan, J.L. The ICS-'BPH' study: The psychometric validity and reliability of the ICSmale questionnaire. Br. J. Urol. 1996, 77, 554-562. [CrossRef] [PubMed]

172. Alsaikhan, B.; Alrabeeah, K.; Carrier, S. Management options for the treatment of benign prostatic hyperplasia with or without erectile dysfunction: A focus on tadalafl and patient considerations. Int. J. Gen. Med. 2014, 7, 271. [PubMed]

173. Gonzalez, R.R.; Kaplan, S.A. Tadalafil for the treatment of lower urinary tract symptoms in men with benign prostatic hyperplasia. Expert Opin. Drug Metab. Toxicol. 2006, 2, 609-617. [CrossRef]

174. Giannitsas, K.; Mitropoulos, D.; Konstantinopoulos, A.; Athanasopoulos, A.; Perimenis, P. Phosphodiesterase-5 inhibitors in the treatment of lower urinary tract symptoms and benign prostatic hyperplasia. Expert Opin. Pharmacother. 2008, 9, 1687-1693. [CrossRef] 
175. Govorov, A.; Kasyan, G.; Priymak, D.; Pushkar, D.; Sorsaburu, S. Tadalafil in the management of lower urinary tract symptoms: A review of the literature and current practices in Russia. Cent. Eur. J. Urol. 2014, 67, 167-176. [CrossRef]

176. Hatzimouratidis, K. A review of the use of tadalafil in the treatment of benign prostatic hyperplasia in men with and without erectile dysfunction. Ther. Adv. Urol. 2014, 6, 135-147. [CrossRef]

177. La Vignera, S.; Aversa, A.; Cannarella, R.; Condorelli, R.A.; Duca, Y.; Russo, G.I.; Calogero, A.E. Pharmacological treatment of lower urinary tract symptoms in benign prostatic hyperplasia: Consequences on sexual function and possible endocrine effects. Expert Opin. Pharmacother. 2021, 22, 179-189. [CrossRef] [PubMed]

178. Lythgoe, C.; McVary, K.T. The use of PDE-5 inhibitors in the treatment of lower urinary tract symptoms due to benign prostatic hyperplasia. Curr. Urol. Rep. 2013, 14, 585-594. [CrossRef] [PubMed]

179. Martínez-Salamanca, J.I.; Carballido, J.; Eardley, I.; Giuliano, F.; Gratzke, C.; Rosen, R.; Salonia, A.; Stief, C. Phosphodiesterase type 5 inhibitors in the management of non-neurogenic male lower urinary tract symptoms: Critical analysis of current evidence. Eur. Urol. 2011, 60, 527-535. [CrossRef] [PubMed]

180. Olesovsky, C.; Kapoor, A. Evidence for the efficacy and safety of tadalafil and finasteride in combination for the treatment of lower urinary tract symptoms and erectile dysfunction in men with benign prostatic hyperplasia. Ther. Adv. Urol. 2016, 8, 257-271. [CrossRef] [PubMed]

181. Porst, H.; Roehrborn, C.G.; Secrest, R.J.; Esler, A.; Viktrup, L. Effects of tadalafil on lower urinary tract symptoms secondary to benign prostatic hyperplasia and on erectile dysfunction in sexually active men with both conditions: Analyses of pooled data from four randomized, placebo-controlled tadalafil clinical stu. J. Sex. Med. 2013, 10, 2044-2052. [CrossRef]

182. Ückert, S.; Oelke, M. Phosphodiesterase (PDE) inhibitors in the treatment of lower urinary tract dysfunction. Br. J. Clin. Pharmacol. 2011, 72, 197-204. [CrossRef] [PubMed]

183. Andersson, K.E.; De Groat, W.C.; McVary, K.T.; Lue, T.F.; Maggi, M.; Roehrborn, C.G.; Wyndaele, J.J.; Melby, T.; Viktrup, L. Tadalafil for the treatment of lower urinary tract symptoms secondary to benign prostatic hyperplasia: Pathophysiology and mechanism(s) of action. Neurourol. Urodyn. 2011, 30, 292-301. [CrossRef]

184. Wang, X.; Wang, X.; Li, S.; Meng, Z.; Liu, T.; Zhang, X. Comparative effectiveness of oral drug therapies for lower urinary tract symptoms due to benign prostatic hyperplasia: A systematic review and network meta-Analysis. PLoS ONE 2014, 9, e107593. [CrossRef]

185. Wroński, S. The new horizons of pharmacotherapy. Unexpected pharmacological actions and a new therapeutic strategy of phosphodiesterase-5 inhibitors. Cent. Eur. J. Urol. 2014, 67, 314-318. [CrossRef]

186. Yan, H.; Zong, H.; Cui, Y.; Li, N.; Zhang, Y. The Efficacy of PDE5 Inhibitors Alone or in Combination with Alpha-Blockers for the Treatment of Erectile Dysfunction and Lower Urinary Tract Symptoms Due to Benign Prostatic Hyperplasia: A Systematic Review and Meta-Analysis. J. Sex. Med. 2014, 11, 1539-1545. [CrossRef]

187. Zhao, C.; Kwan Park, J. Phosphodiesterase Type 5 Inhibitor and Erectile Dysfunction in Lower Urinary Tract Symptoms. LUTS Lower Urin. Tract Symptoms 2012, 4 (Suppl. 1), 75-80. [CrossRef]

188. Elterman, D.S.; Chughtai, B.; Lee, R.K.; Te, A.E.; Kaplan, S.A. Update on Phosphodiesterase Type 5 Inhibitors for the Treatment of Lower Urinary Tract Symptoms due to Benign Prostatic Hyperplasia. Rev. Urol. 2012, 14, 79-86.

189. Lee, J.Y.; Park, S.Y.; Jeong, T.Y.; Moon, H.S.; Kim, Y.T.; Yoo, T.K.; Choi, H.Y.; Park, H.Y.; Lee, S.W. Combined tadalafil and $\alpha$-blocker therapy for benign prostatic hyperplasia in patients with erectile dysfunction: A multicenter, prospective study. J. Androl. 2012, 33, 397-403. [CrossRef]

190. Miller, M.S. El Rol de los inhibidores de la fosfodiesterasa tipo 5 para síntomas del tracto urinario. Ann. Pharmacother. 2013, 47, 278-283. [CrossRef] [PubMed]

191. Park, H.J.; Won, J.E.J.; Sorsaburu, S.; Rivera, P.D.; Lee, S.W. Urinary Tract Symptoms (LUTS) Secondary to Benign Prostatic Hyperplasia (BPH) and LUTS/BPH with Erectile Dysfunction in Asian Men: A Systematic Review Focusing on Tadalafil. World J. Mens Health 2013, 31, 193. [CrossRef]

192. Giuliano, F.; Rouprêt, M.; Doridot, G.; de la Taille, A. Effects of phosphodiesterase type 5 inhibitors on lower urinary tract symptoms secondary to benign prostatic hyperplasia. Prog. Urol. 2013, 23, 283-295. [CrossRef] [PubMed]

193. Giuliano, F.; Ückert, S.; Maggi, M.; Birder, L.; Kissel, J.; Viktrup, L. The mechanism of action of phosphodiesterase type 5 inhibitors in the treatment of lower urinary tract symptoms related to benign prostatic hyperplasia. Eur. Urol. 2013, 63, 506-516. [CrossRef]

194. Caremel, R.; Oger-Roussel, S.; Behr-Roussel, D.; Grise, P.; Giuliano, F. Traitement des troubles du bas appareil urinaire liésà une hyperplasie bénigne de prostate par inhibiteurde la phosphodiestérase de type 5. Prog. Urol. 2010, 20, 616-626. [CrossRef] [PubMed]

195. Tadalafil for benign prostatic hyperplasia. Drug Ther. Bull. 2013, 51, 93-96. [CrossRef] [PubMed]

196. Carson, C.C. Combination of phosphodiesterase- 5 inhibitors and $\alpha$-blockers in patients with benign prostatic hyperplasia: Treatments of lower urinary tract symptoms, erectile dysfunction, or both? BJU Int. 2006, 97 (Suppl. 2), 39-43. [CrossRef]

197. Curran, M.P. Tadalafil: In the treatment of signs and symptoms of benign prostatic hyperplasia with or without erectile dysfunction. Drugs Aging 2012, 29, 771-781. [CrossRef] [PubMed]

198. Dong, Y.; Hao, L.; Shi, Z.; Wang, G.; Zhang, Z.; Han, C. Efficacy and safety of tadalafil monotherapy for lower urinary tract symptoms secondary to benign prostatic hyperplasia: A meta-analysis. Urol. Int. 2013, 91, 10-18. [CrossRef] 
199. Gacci, M.; Vittori, G.; Tosi, N.; Siena, G.; Rossetti, M.A.; Lapini, A.; Vignozzi, L.; Serni, S.; Maggi, M.; Carini, M. A Randomized, Placebo-Controlled Study to Assess Safety and Efficacy of Vardenafil $10 \mathrm{mg}$ and Tamsulosin $0.4 \mathrm{mg}$ vs. Tamsulosin $0.4 \mathrm{mg}$ Alone in the Treatment of Lower Urinary Tract Symptoms Secondary to Benign Prostatic Hyperplasia. J. Sex. Med. 2012, 9, 1624-1633. [CrossRef] [PubMed]

200. Gacci, M.; Salvi, M.; Sebastianelli, A.; Vignozzi, L.; Corona, G.; Mcvary, K.T.; Refidaff, C.; Maggi, M.; Carini, M.; Oelke, M. The use of a single daily dose of tadalafil to treat signs and symptoms of benign prostatic hyperplasia and erectile dysfunction. Open Access J. Urol. 2013, 5, 99-111. [CrossRef] [PubMed]

201. Gales, B.J.; Gales, M.A. Phosphodiesterase-5 inhibitors for lower urinary tract symptoms in men. Ann. Pharmacother. 2008, 42, 111-115. [CrossRef] [PubMed]

202. Bechara, A.; Romano, S.; Casabé, A.; Haime, S.; Dedola, P.; Hernández, C.; Rey, H. Comparative efficacy assessment of tamsulosin vs. tamsulosin plus tadalafil in the treatment of LUTS/BPH. pilot study. J. Sex. Med. 2008, 5, 2170-2178. [CrossRef]

203. Glina, S.; Roehrborn, C.G.; Esen, A.; Plekhanov, A.; Sorsaburu, S.; Henneges, C.; Büttner, H.; Viktrup, L. Sexual Function in Men with Lower Urinary Tract Symptoms and Prostatic Enlargement Secondary to Benign Prostatic Hyperplasia: Results of a 6-Month, Randomized, Double-Blind, Placebo-Controlled Study of Tadalafil Coadministered with Finasteride. J. Sex. Med. 2015, 12, 129-138. [CrossRef]

204. Kim, S.C.; Park, J.K.; Kim, S.W.; Lee, S.W.; Ahn, T.Y.; Kim, J.J.; Paick, J.S.; Park, N.C.; Park, K.; Min, K.S.; et al. Tadalafil Administered Once Daily for Treatment of Lower Urinary Tract Symptoms in Korean men with Benign Prostatic Hyperplasia: Results from a Placebo-Controlled Pilot Study Using Tamsulosin as an Active Control. LUTS Low Urin Tract Symptoms 2011, 3 , 86-93. [CrossRef]

205. Kim, S.W.; Park, N.C.; Lee, S.W.; Yang, D.Y.; Park, J.K.; Moon, D.G.; Yang, S.K.; Lee, S.W.; Moon, K.H.; Ahn, T.Y.; et al. Efficacy and Safety of a Fixed-Dose Combination Therapy of Tamsulosin and Tadalafil for Patients with Lower Urinary Tract Symptoms and Erectile Dysfunction: Results of a Randomized, Double-Blinded, Active-Controlled Trial. J. Sex. Med. 2017, 14, 1018-1027. [CrossRef]

206. Oelke, M.; Giuliano, F.; Mirone, V.; Xu, L.; Cox, D.; Viktrup, L. Monotherapy with tadalafil or tamsulosin similarly improved lower urinary tract symptoms suggestive of benign prostatic hyperplasia in an international, randomised, parallel, placebo-controlled clinical trial. Eur. Urol. 2012, 61, 917-925. [CrossRef]

207. Öztürk, M.I.; Kalkan, S.; Koca, O.; Güneş, M.; Akyüz, M.; Karaman, M.I. Efficacy of alfuzosin and sildenafil combination in male patients with lower urinary tract symptoms. Andrologia 2012, 44 (Suppl.1), 791-795. [CrossRef] [PubMed]

208. Porst, H.; Kim, E.D.; Casabé, A.R.; Mirone, V.; Secrest, R.J.; Xu, L.; Sundin, D.P.; Viktrup, L. Efficacy and safety of tadalafil once daily in the treatment of men with lower urinary tract symptoms suggestive of benign prostatic hyperplasia: Results of an international randomized, double-blind, placebo-controlled trial. Eur. Urol. 2011, 60, 1105-1113. [CrossRef] [PubMed]

209. Stief, C.G.; Porst, H.; Neuser, D.; Beneke, M.; Ulbrich, E. A Randomised, Placebo-Controlled Study to Assess the Efficacy of Twice-Daily Vardenafil in the Treatment of Lower Urinary Tract Symptoms Secondary to Benign Prostatic Hyperplasia. Eur. Urol. 2008, 53, 1236-1244. [CrossRef]

210. Takeda, M.; Nishizawa, O.; Imaoka, T.; Morisaki, Y.; Viktrup, L. Tadalafil for the Treatment of Lower Urinary Tract Symptoms in Japanese Men with Benign Prostatic Hyperplasia: Results from a 12-week Placebo-controlled Dose-finding Study with a 42-week Open-label Extension. LUTS Low Urin. Tract Symptoms 2012, 4, 110-119. [CrossRef] [PubMed]

211. Takeda, M.; Yokoyama, O.; Lee, S.W.; Murakami, M.; Morisaki, Y.; Viktrup, L. Tadalafil 5 mg once-daily therapy for men with lower urinary tract symptoms suggestive of benign prostatic hyperplasia: Results from a randomized, double-blind, placebo-controlled trial carried out in Japan and Korea. Int. J. Urol. 2014, 21, 670-675. [CrossRef]

212. Tamimi, N.A.M.; Mincik, I.; Haughie, S.; Lamb, J.; Crossland, A.; Ellis, P. A placebo-controlled study investigating the efficacy and safety of the phosphodiesterase type 5 inhibitor UK-369,003 for the treatment of men with lower urinary tract symptoms associated with clinical benign prostatic hyperplasia. BJU Int. 2010, 106, 674-680. [CrossRef]

213. Brock, G.; Broderick, G.; Roehrborn, C.G.; Xu, L.; Wong, D.; Viktrup, L. Tadalafil once daily in the treatment of lower urinary tract symptoms (LUTS) suggestive of benign prostatic hyperplasia (BPH) in men without erectile dysfunction. BJU Int. 2013, 112, 990-997. [CrossRef]

214. Tuncel, A.; Nalcacioglu, V.; Ener, K.; Aslan, Y.; Aydin, O.; Atan, A. Sildenafil citrate and tamsulosin combination is not superior to monotherapy in treating lower urinary tract symptoms and erectile dysfunction. World J. Urol. 2010, 28, 17-22. [CrossRef]

215. Yokoyama, O.; Yoshida, M.; Kim, S.C.; Wang, C.J.; Imaoka, T.; Morisaki, Y.; Viktrup, L. Tadalafil once daily for lower urinary tract symptoms suggestive of benign prostatic hyperplasia: A randomized placebo- and tamsulosin-controlled 12-week study in Asian men. Int. J. Urol. 2013, 20, 193-201. [CrossRef]

216. McVary, K.T.; Monnig, W.; Camps, J.L.; Young, J.M.; Tseng, L.J.; van den Ende, G. Sildenafil Citrate Improves Erectile Function and Urinary Symptoms in Men with Erectile Dysfunction and Lower Urinary Tract Symptoms Associated with Benign Prostatic Hyperplasia: A Randomized, Double-Blind Trial. J. Urol. 2007, 177, 1071-1077. [CrossRef]

217. McVary, K.T.; Roehrborn, C.G.; Kaminetsky, J.C.; Auerbach, S.M.; Wachs, B.; Young, J.M.; Esler, A.; Sides, G.D.; Denes, B.S. Tadalafil Relieves Lower Urinary Tract Symptoms Secondary to Benign Prostatic Hyperplasia. J. Urol. 2007, 177, $1401-1407$. [CrossRef] 
218. Broderick, G.A.; Brock, G.B.; Roehrborn, C.G.; Watts, S.D.; Elion-Mboussa, A.; Viktrup, L. Effects of Tadalafil on Lower Urinary Tract Symptoms Secondary to Benign Prostatic Hyperplasia in Men with or with out Erectile Dysfunction. Urology 2010, 75, 1452-1457. [CrossRef] [PubMed]

219. Casabé, A.; Roehrborn, C.G.; Da Pozzo, L.F.; Zepeda, S.; Henderson, R.J.; Sorsaburu, S.; Henneges, C.; Wong, D.G.; Viktrup, L. Efficacy and safety of the coadministration of tadalafil once daily with finasteride for 6 months in men with lower urinary tract symptoms and prostatic enlargement secondary to benign prostatic hyperplasia. J. Urol. 2014, 191, 727-733. [CrossRef] [PubMed]

220. Dmochowski, R.; Roehrborn, C.; Klise, S.; Xu, L.; Kaminetsky, J.; Kraus, S. Urodynamic effects of once daily tadalafil in men with lower urinary tract symptoms secondary to clinical benign prostatic hyperplasia: A randomized, placebo controlled 12-week clinical trial. J. Urol. 2010, 189 (Suppl. 1), 1092-1097. [CrossRef] [PubMed]

221. Egerdie, R.B.; Auerbach, S.; Roehrborn, C.G.; Costa, P.; Garza, M.S.; Esler, A.L.; Wong, D.G.; Secrest, R.J. Tadalafil 2.5 or 5 $\mathrm{mg}$ administered once daily for 12 weeks in men with both erectile dysfunction and signs and symptoms of benign prostatic hyperplasia: Results of a randomized, placebo-controlled, double-blind study. J. Sex. Med. 2012, 9, 271-281. [CrossRef]

222. Gacci, M.; Corona, G.; Salvi, M.; Vignozzi, L.; McVary, K.T.; Kaplan, S.A.; Roehrborn, C.G.; Serni, S.; Mirone, V.; Carini, M.; et al. A systematic review and meta-analysis on the use of phosphodiesterase 5 inhibitors alone or in combination with $\alpha$-blockers for lower urinary tract symptoms due to benign prostatic hyperplasia. Eur. Urol. 2012, 61, 994-1003. [CrossRef]

223. Giuliano, F.A.; Lamb, J.; Crossland, A.; Haughie, S.; Ellis, P.; Tamimi, N.A.M. A placebo-controlled exploratory study investigating the efficacy and safety of the phosphodiesterase type 5 inhibitor UK-369,003 for the treatment of men with storage lower urinary tract symptoms associated with a clinical diagnosis of overactive bladder. BJU Int. 2010, 106, 666-673. [CrossRef]

224. Giuliano, F.; Oelke, M.; Jungwirth, A.; Hatzimouratidis, K.; Watts, S.; Cox, D.; Viktrup, L. Tadalafil Once Daily Improves Ejaculatory Function, Erectile Function, and Sexual Satisfaction in Men with Lower Urinary Tract Symptoms Suggestive of Benign Prostatic Hyperplasia and Erectile Dysfunction: Results from a Randomized, Placebo- and Tamsulosin. J. Sex. Med. 2013, 10, 857-865. [CrossRef] [PubMed]

225. Donatucci, C.F.; Brock, G.B.; Goldfischer, E.R.; Pommerville, P.J.; Elion-Mboussa, A.; Kissel, J.D.; Viktrup, L. Tadalafil administered once daily for lower urinary tract symptoms secondary to benign prostatic hyperplasia: A 1-year, open-label extension study. BJU Int. 2011, 107, 1110-1116. [CrossRef]

226. Kaplan, S.A.; Gonzalez, R.R.; Te, A.E. Combination of Alfuzosin and Sildenafil is Superior to Monotherapy in Treating Lower Urinary Tract Symptoms and Erectile Dysfunction. Eur. Urol. 2007, 51, 1717-1723. [CrossRef]

227. Liguori, G.; Trombetta, C.; De Giorgi, G.; Pomara, G.; Maio, G.; Vecchio, D.; Ocello, G.; Ollandini, G.; Bucci, S.; Belgrano, E. Efficacy and safety of combined oral therapy with tadalafil and alfuzosin: An integrated approach to the management of patients with lower urinary tract symptoms and erectile dysfunction. Preliminary report. J. Sex. Med. 2009, 6, 544-552. [CrossRef] [PubMed]

228. MacDiarmid, S.A.; Hill, L.A.; Volinn, W.; Hoel, G. Lack of Pharmacodynamic Interaction of Silodosin, a Highly Selective $\alpha 1 a-$ Adrenoceptor Antagonist, with the Phosphodiesterase-5 Inhibitors Sildenafil and Tadalafil in Healthy Men. Urology 2010, 75, 520-525. [CrossRef]

229. Mulhall, J.P.; Guhring, P.; Parker, M.; Hopps, C. Assessment of the impact of sildenafil citrate on lower urinary tract symptoms in men with erectile dysfunction. J. Sex. Med. 2006, 3, 662-667. [CrossRef]

230. Sairam, K.; Kulinskaya, E.; McNicholas, T.A.; Boustead, G.B.; Hanbury, D.C. Sildenafil influences lower urinary tract symptoms. BJU Int. 2002, 90, 836-839. [CrossRef]

231. Singh, D.V.; Mete, U.K.; Mandal, A.K.; Singh, S.K. A Comparative Randomized Prospective Study to Evaluate Efficacy and Safety of Combination of Tamsulosin and Tadalafil vs. Tamsulosin or Tadalafil Alone in Patients with Lower Urinary Tract Symptoms due to Benign Prostatic Hyperplasia. J. Sex. Med. 2014, 11, 187-196. [CrossRef]

232. Torre, A.L.; Giupponi, G.; Duffy, D.; Conca, A.; Cai, T.; Scardigli, A. Sexual Dysfunction Related to Drugs: A Critical ReviewPart V: $\alpha$-Blocker and 5-ARI Drugs. Pharmacopsychiatry 2015, 49, 3-13. [CrossRef]

233. Gupta, A.K.; Carviel, J.; MacLeod, M.A.; Shear, N. Assessing finasteride-associated sexual dysfunction using the FAERS database. J. Eur. Acad. Dermatol. Venereol. 2017, 31, 1069-1075. [CrossRef] [PubMed]

234. Yu, H.-J.; Chung, S.-D. Impact of Treatment of Lower Urinary Tract Symptoms Suggestive of Benign Prostatic Hyperplasia in Ageing Men. BJU Int. 2007, 95, 12-18.

235. De Rose, A.F.; Carmignani, G.; Corbu, C.; Giglio, M.; Traverso, P.; Naselli, A.; Belgrano, E.; Catuogno, C.; Fontana, D.; Maver, A.; et al. Observational multicentric trial performed with doxazosin: Evaluation of sexual effects on patients with diagnosed benign prostatic hyperplasia. Urol. Int. 2002, 68, 95-98. [CrossRef]

236. Barkin, J. Review of dutasteride/tamsulosin fixed-dose combination for the treatment of benign prostatic hyperplasia: Efficacy, safety, and patient acceptability. Patient Prefer. Adherence 2011, 5, 483. [CrossRef]

237. Traish, A.M. Post-finasteride syndrome: A surmountable challenge for clinicians. Fertil. Steril. 2020, 113, 21-50. [CrossRef] [PubMed]

238. ICD. ICD-1-International Classification of Diseases, Tenth Revision. Available online: https://www.cdc.gov/nchs/icd/icd10.htm (accessed on 1 July 2021). 